\title{
Beneficial Effects of Spices in Food Preservation and Safety
}

\author{
Davide Gottardi ${ }^{1}$, Danka Bukvicki ${ }^{2}$, Sahdeo Prasad ${ }^{3}$ and Amit K. Tyagi ${ }^{1,3 *}$ \\ ${ }^{1}$ Department of Agricultural and Food Sciences, Alma Mater Studiorum, University of Bologna, Cesena, Italy, ${ }^{2}$ Faculty of \\ Biology, Institute of Botany and Botanical Garden "Jevremovac", University of Belgrade, Belgrade, Serbia, ${ }^{3}$ Division of Cancer \\ Medicine, Department of Experimental Therapeutics, The University of Texas MD Anderson Cancer Center, Houston, TX, USA
}

Spices have been used since ancient times. Although they have been employed mainly as flavoring and coloring agents, their role in food safety and preservation have also been studied in vitro and in vivo. Spices have exhibited numerous health benefits in preventing and treating a wide variety of diseases such as cancer, aging, metabolic, neurological, cardiovascular, and inflammatory diseases. The present review aims to provide a comprehensive summary of the most relevant and recent findings on spices and their active compounds in terms of targets and mode of action; in particular, their potential use in food preservation and enhancement of shelf life as a natural bioingredient.

Keywords: inflammatory diseases, spices, food preservation, disease prevention, antimicrobial

\section{OPEN ACCESS}

Edited by:

Michael Gänzle

University of Alberta, Canada

Reviewed by:

Carlos F. Torres,

Autonomous University of Madrid,

Spain

Chibundu Ngozi Ezekiel, Babcock University, Nigeria

${ }^{*}$ Correspondence:

Amit K. Tyagi

amittyagiiitd@gmail.com; akumar6@mdanderson.org

Specialty section:

This article was submitted to Food Microbiology,

a section of the journal

Frontiers in Microbiology

Received: 20 January 2016

Accepted: 23 August 2016 Published: 21 September 2016

Citation:

Gottardi D, Bukvicki D, Prasad S and

Tyagi AK (2016) Beneficial Effects of

Spices in Food Preservation and

Safety. Front. Microbiol. 7:1394.

doi: 10.3389/fmicb.2016.01394

\section{INTRODUCTION}

Plant, animal, and microbes represent an unlimited source of compounds with medicinal properties (Tajkarimi et al., 2010). Since ancient time, humans are using spices as nutritional agents (Kaefer and Milner, 2008). According to the U.S. Food and Drug Administration (FDA), spice is an "aromatic vegetable substance in the whole, broken, or ground form, the significant function of which in food is seasoning rather than nutrition" and from which "no portion of any volatile oil or other flavoring principle has been removed" (Sung et al., 2012).

More than 100 varieties of spices are produced throughout the world. Asia is the main leader for the production of spices, particularly of cinnamon, pepper, nutmeg, cloves, and ginger, while Europe grows mainly basil, bay leaves, celery leaves, chives, coriander, dill tips, thyme, and watercress. In America, instead, pepper, nutmeg, ginger, allspice, and sesame seed are mainly produced (Prasad et al., 2011).

Although spices have been used (mostly dried seed, fruit, root, bark, or vegetative material) for rituals, cosmetics and perfumery, their flavoring, coloring and, especially, preservative properties have founded wide applications both in the traditional food preparations and in the food industry. In fact, many compounds isolated from spices (Table 1) have shown antimicrobial activity against some of the most common microorganisms that affect the food quality and shelf life (Tajkarimi et al., 2010). The introduction of spices through the meals has various beneficial effects as well. For instance, they can stimulate the secretion of saliva, promote the digestion, prevent from cold and influenza, and reduce nausea and vomiting (Ravindran, 2002; Sultana et al., 2010). In this manuscript we provide an overview on spices and their constituent as a natural food preservatives in vitro and in vivo.

\section{IMPORTANCE OF SPICES}

Spices have been important to mankind since the beginning of history. Several mythological evidence including "Epic of Gilgamaesh," and the "Bagavad Gita," suggest their use for several 
TABLE 1 | Antimicrobial potential of phytochemicals (spices) for food preservation; In vitro study.

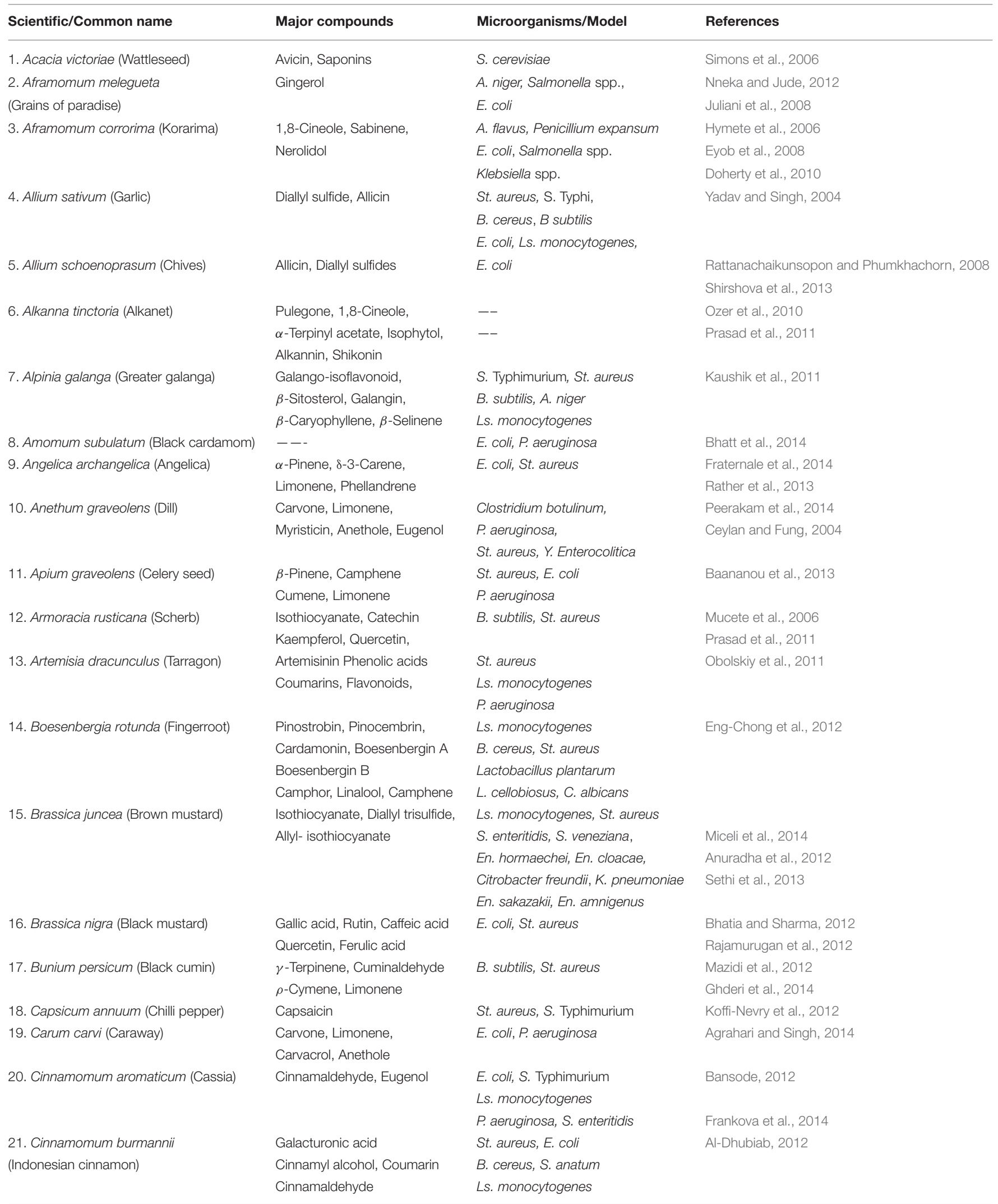




\section{TABLE 1 | Continued}

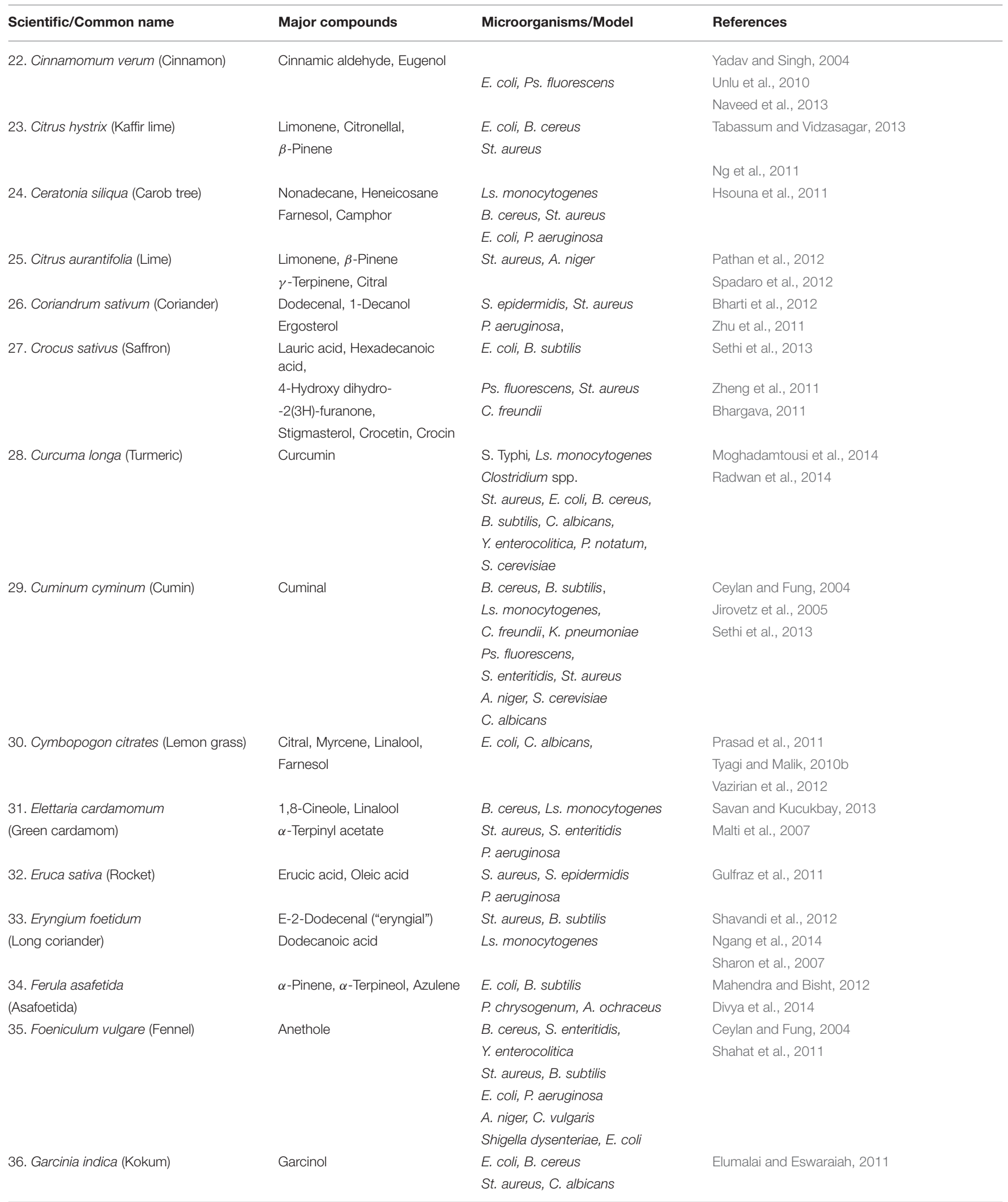




\section{TABLE 1 | Continued}

Scientific/Common name
37. Heracleum persicum (Golpar)
38. Hyssopus officinalis (Hyssop)
39. Houttuynia cordata
(Chameleon plant)
40. Illicium verum (Star anise)
41. Kaempferia galanga (Kencur)

42. Laurus nobilis (Bay)

43. Lavandula angustifolia

44. Limnophila aromatic

(Finger grass)

45. Lippia adoensis (Koseret)

46. Lippia graveolens

(Mexican oregano)

47. Maranta arundinacea (Arrowroot)

48. Melissa officinalis (Balm)

49. Mentha piperita (Mint)

50. Monodora myristica
(Calabash nutmeg)
51. Murraya koenigii
(Curry leaf)
52. Myrica gale (Gale)
53. Myristica fragrans
(Nutmeg)

54. Myrrhis odorata (Cicely)

\section{Major compounds}

Pimpinellin, Isopimpinellin Bergapten, Isobergapten Isopinocamphone,

Terpinen-4-ol

Pinocarvone, Carvacrol

Aristolactams, Houttuynoside

A

Quercitrin, Quercetin-3-O- $\beta$-D-

-galactopyranoside

Shikimic acid, Anethole

Ethyl-cinnamate, 1,8-cineole

Camphene, Borneol,

Kaempferol

Kaempferide

1,8-Cineole, $\alpha$-Pinene,

Limonene

2-Carene

1,8-Cineole, Camphor,

Borneole

(Lavender)

Ocimene, Terpinolene,

Camphor

Linalool, Germacrene D

Thymol, Carvacrol, flavonoids

Flavonoids, terpenoids

Neral, Citronellal, Isomenthone,

Menthone, $\beta$-Caryophyllene,

Carvacrol

Menthol; 1,8-cineole

Cymene, $\alpha$-Phellandrene

Germacrene D-4-ol

Murrayanol

Murrayacine, Mahanine

Cymene, $\beta$-Elemene,

Myrcene, Limonene

Myristicin, Sabinene

$\beta$-Pinene

p-Cymene, $\alpha$-Terpinene,

$\delta$-Cadinene
Microorganisms/Model

C. albicans

St. aureus

E. coli, S. Typhimurium,

C. albicans, S. aureus

S. Typhimurium

B. cereus

St. aureus, E. coli

C. albicans

Alternaria alternata, E. coli

St. aureus

$P$. aeruginosa, E. coli

St. aureus, B. cereus

S. epidermidis

St. aureus, C. albicans

S. cerevisiae

M. luteus, Salmonella spp.

Aspergillus niger

Herpes simplex virus

human respiratory syncytial virus

and human rotavirus

E. coli, Ls. monocytogenes,

S. enteritidis, St. aureus

Shigella sonnei

E. coli, $P$. aeruginosa, St. aureus,

Streptococcus faecalis, C. albicans

St. aureus, B. cereus

C. albicans

Staphylococus sp.

St. aureus, B. subtilis

S. cerevisiae, C. albicans

St. aureus, B. subtilis

$P$. aeruginosa, $A$. niger

Clostridium spp.

E. coli, St. aureus,

C. albicans, A. niger

\section{References}

Hemati et al., 2010

Di Pasqua et al., 2005

Süleyman et al., 2010

Kumar et al., 2014

Shan et al., 2007

Umar et al., 2011

Xu et al., 2014

Cherrat et al., 2014

Cavanagh and Wilkinson, 2005

Torabbeigi and Azar, 2013

Gorai et al., 2014

Folashade and Egharevba, 2012

Hernández-Hernández et al., 2014

Pilau et al., 2011

Kim and Fung, 2003

Rajashekhara et al., 2013

Moradkhani et al., 2010

Sharafi et al., 2010

Saharkhiz et al., 2012

McKay and Blumberg, 2006

Tyagi et al., 2013

Owokotomo and Ekundayo, 2012

Odoh et al., 2004

Handral et al., 2012

Nakata et al., 2013

Gupta et al., 2013b

Radwan et al., 2014

Rancic et al., 2005 


\section{TABLE 1 | Continued}

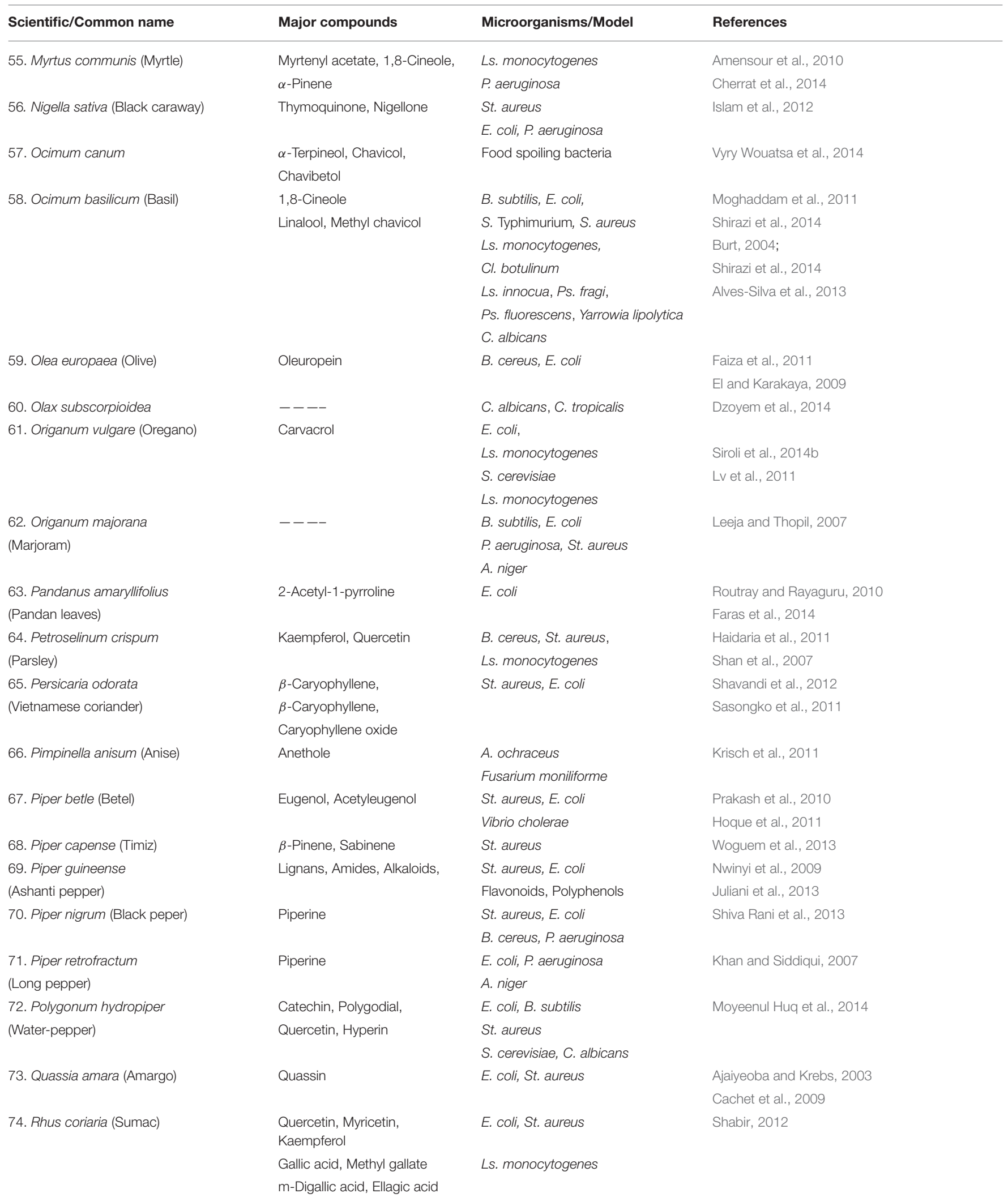


TABLE 1 | Continued

\begin{tabular}{|c|c|c|c|}
\hline Scientific/Common name & Major compounds & Microorganisms/Model & References \\
\hline (Rosemary) & Thymol, $\gamma$-Terpinene, & Brochothrix thermosphacta & Özcan and Chalchat, 2008 \\
\hline \multirow[t]{2}{*}{ 76. Ruta graveolens (Rue) } & Rutin & St. aureus, E. coli & Hamad, 2012 \\
\hline & & & Kumar et al., 2014 \\
\hline \multirow[t]{2}{*}{ 79. Sassafras albidum (Sassafras) } & Safrole, Camphor, & $P$. aeruginosa, & Kamdem and Douglas, 2007 \\
\hline & Methyl eugenol & S. Typhimurium & Barbosa et al., 2012 \\
\hline \multirow[t]{2}{*}{ 80. Satureja hortensis (Summer savory) } & $\begin{array}{l}\text { Carvacrol, } \gamma \text {-terpinene, } \\
p \text {-cymene }\end{array}$ & B. subtilis, $P$. aeruginosa, & Mihajlov-Krstev et al., 2010 \\
\hline & & C. albicans, S. cerevisiae & \\
\hline \multirow[t]{2}{*}{ 83. Sesamum indicum (Sesame) } & Latifonin, Momor-cerebroside, & E. coli & Ogunsola and Fasola, 2014 \\
\hline & Soya-cerebroside & & Hu et al., 2007 \\
\hline \multirow[t]{2}{*}{ 84. Sinapis alba (White mustard) } & Benzyl isothiocyanate & E. coli & Al-Qudah et al., 2011 \\
\hline & Benzyl nitrile, thymol & & \\
\hline 85. Smyrnium olusatrum & Sabinene, Curzerene & ---- & Mokaddem et al., 2010 \\
\hline (Alexanders) & $\alpha$-Pinene, Cryptone & & \\
\hline 86. Syzygium aromaticum & Eugenol & E. coli, St. aureus & Yadav and Singh, 2004 \\
\hline \multirow[t]{3}{*}{ (Clove) } & & S. anatum, B. cereus & Naveena et al., 2006 \\
\hline & & C. freundii, K. pneumoniae & Shan et al., 2007 \\
\hline & & & Sethi et al., 2013 \\
\hline \multirow[t]{4}{*}{ 89. Thymus vulgaris (Thyme) } & Thymol, Cinnamaldehyde & & Burt, 2004 \\
\hline & & & Jayasena and Jo, 2013 \\
\hline & & Ls. monocytogenes, & \\
\hline & & P. putida & \\
\hline 90. Thymus capitatus & Thymol, Camphor, & B. cereus, Salmonella sp. & Boubaker et al., 2013 \\
\hline (Headed Savory) & Carvacrol & Ls. innocua & Bounatirou et al., 2007 \\
\hline 91. Thymus serpyllum & Thymol, Carvacrol & Ls. monocytogenes & Skrinjar and Nemet, 2009 \\
\hline (Breckland thyme) & & St. aureus, E. coli & Paaver et al., 2008 \\
\hline 92. Trigonella foenum-graecum & Trigonelline & E. coli, B. cereus & Upadhyay et al., 2008 \\
\hline (Fenugreek) & Kaempferol 7-O-glucoside & & Omezzine et al., 2014 \\
\hline 93. Trachyspermum ammi & $\beta$-Phellandrene, $\alpha$-Terpinene, & C. albicans, Salmonella spp., & Khan et al., 2010 \\
\hline \multirow[t]{2}{*}{ (Ajwan) } & Limonene & St. aureus, E. coli & Chauhan et al., 2012 \\
\hline & & S. Typhimurium & \\
\hline \multirow[t]{3}{*}{ 94. Vanilla planifolia } & Vanillin, Vanillic acid & E. coli, B. cereus & Menon and Nayeem, 2013 \\
\hline & (Vanilla) & S. cerevisiae, & Fitzgerald et al., 2003 \\
\hline & & Zygosaccharomyces bailii, Z. rouxii & Shanmugavalli et al., 2009 \\
\hline
\end{tabular}


TABLE 1 | Continued

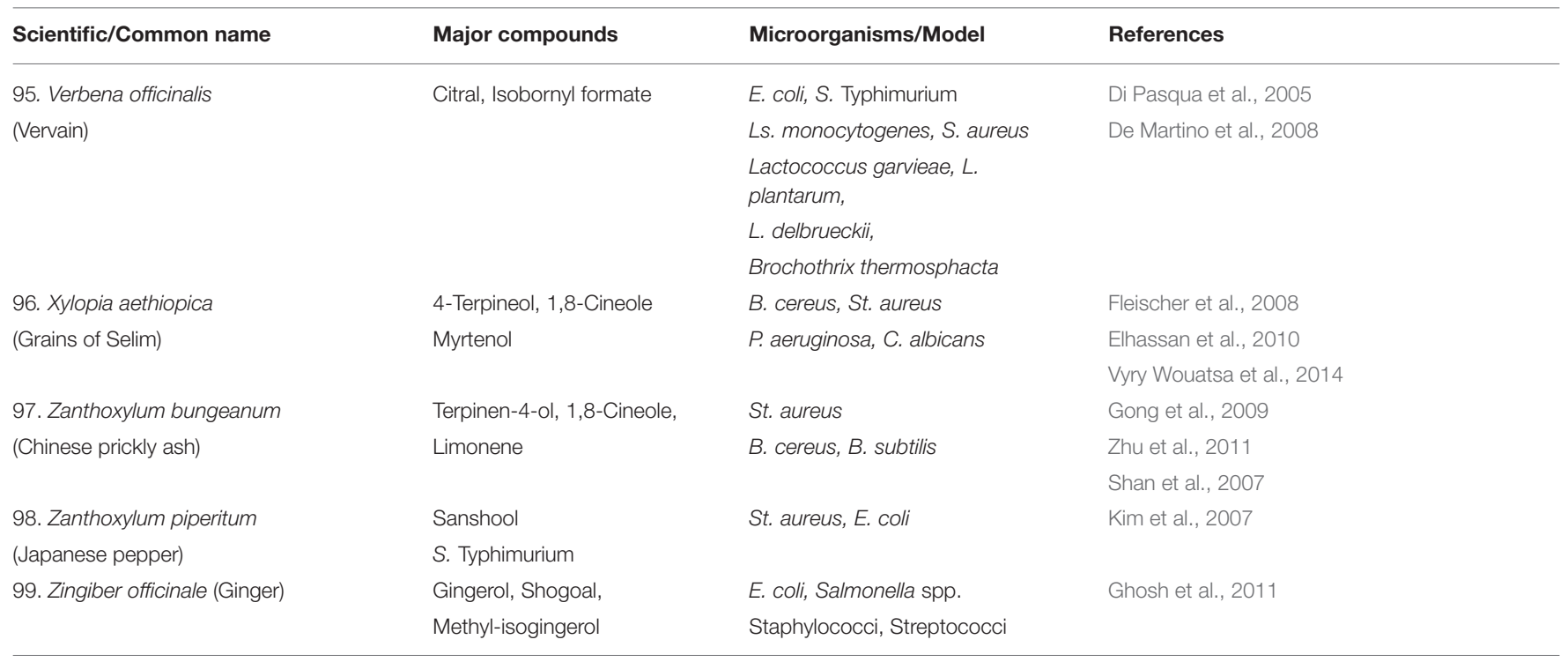

purposes. Because of their strong preservative quality, spices were also used for embalming. According to Ayurveda, they help to maintain the balance of the body humors (Gupta et al., 2013a). Besides these, spices have been used to change the physical appearance of food. For instance, pepper and turmeric changed the color, appearance and the taste of food with many health benefits. Ginger, nutmeg and cinnamon improve digestion, considered good for spleen and sore throats (Prasad et al., 2011). Unfortunately, this beneficial effect of spices is not clinically proven. However, traditional practices emphasize the health benefits of spices. Eventually, recent studies highlighted other biological functions of spices, including antimicrobial, antioxidant, and anti-inflammatory (Tajkarimi et al., 2010).

\section{SPICES FOR FOOD PRESERVATION AND SAFETY}

Food spoilage refers to an irreversible modification in which food becomes not edible or its quality is compromised. Such changes can be driven by different factors, either physical (oxygen, temperature, light) and/or biological (enzymatic activity and microbial growth). Despite the current technologies available in the production chain (for instance freezing, pasteurization, drying, preservatives), it seems impossible to eliminate completely the risk of food spoilage (Gutierrez et al., 2009). Lipid oxidation is one of the main issues of food spoilage. Hence, food industries have applied antioxidants such as butylated hydroxytoluene (BHT) and butylated hydroxyanisole (BHA) to prevent spoilage (Stoilova et al., 2007). However, their safety is doubtful and consumers are progressively demanding natural compounds. For this reason spices represent a potent tool for the food industry, thanks to their natural properties (Hyldgaard et al., 2012). Indeed spices possess antioxidant capacity, mainly due to the presence of phenolic compounds (Figures 1A,B). They exhibit antioxidant property by scavenging free radicals, chelating transition metals, quenching of singlet oxygen, and enhancing the activities of antioxidant enzymes (Rubió et al., 2013). Stoilova et al. (2007) reported that the $\mathrm{CO}_{2}$ extract of ginger had in vitro activity comparable with that of BHT in inhibiting the lipid peroxidation both at 37 and $80^{\circ} \mathrm{C}$. Moreover, pimento and black pepper extracts reduced the formation of acrylamide up to 75 and $50 \%$, respectively, in a model mixture simulating heated potato matrix $\left(180^{\circ} \mathrm{C}\right.$ for $20 \mathrm{~min}$ ). Eugenol, the main component of pimento essential oil, limited the formation of acrylamide by $50 \%$ (Ciesarová et al., 2008). Some other studied antioxidants are: quercetine (dill), capsaicin (red chilli), curcumin (turmeric), carvacrol (oregano, thyme, marjoram), thymol (oregano, thyme), piperine (black pepper), gingerol, etc (ginger, marjoram; Figures 1A,B; Rubió et al., 2013; Przygodzka et al., 2014; Srinivasan, 2014). The relationship between antioxidant properties of spices and food spoilage has been well-documented.

Another issue in food spoilage is the microbial growth. Spices can also exert antimicrobial activity in two ways: by preventing the growth of spoilage microorganisms (food preservation), and by inhibiting/regulating the growth of those pathogenic (food safety; Tajkarimi et al., 2010). Studies regarding in vitro and in vivo antimicrobial activities of spices have been reported in the following sections.

\section{Antimicrobial Activity In vitro}

Numerous articles published in the last few decades have described the antimicrobial activities of spices in vitro. Extracts of entire plants, or part of them, obtained with diverse solvents (such as ethanol, methanol, ethyl acetate, and water) have been tested against microbes (Tajkarimi et al., 2010). Their essential oils or active compounds, alone or in combination, were also used to test the activity against different microbes (Singh et al., 2007; Weerakkody et al., 2010; Bassolé and Juliani, 2012). Disc-diffusion, drop-agar-diffusion, broth microdilution, 
and direct-contact technique in agar represent the most common methods utilized for screening (Tyagi and Malik, 2010a, 2011).

According to these reports, spices possess a very wide spectrum of activity against Gram-positive and Gram-negative bacteria, yeasts and molds (Tajkarimi et al., 2010; Table 1). Alves-Silva et al. (2013) reported that the bush-basil essential oils have antimicrobial activity against Listeria innocua, Serratia marcenscens, Pseudomonas fragi, P. fluorescens, Aeromonas hydrophila, Shewanella putrefaciens, Achromobacter denitrificans, Enterobacter amnigenus, En. gergoviae, and Alcaligenes faecalis, and against the yeasts Yarrowia lipolytica, Saccharomyces cerevisiae, Candida zeylanoides, Debaryomyces hansenii, and Pichia carsonii. Moreover, they were able to inhibit molds such as Mucor racemosus and Penicillium chrysogenum. In the same study, celery and coriander essential oils also showed a very similar antimicrobial activity against the tested strains.

Although the antimicrobial activity of spices may vary according to the types of spice (origin and bioactive compounds), different bacteria can react in different ways (Hyldgaard et al., 2012). Oregano essential oil showed higher antimicrobial activity against Listeria monocytogenes compared to Escherichia coli (Siroli et al., 2014b). Huacatay and basil essential oils were

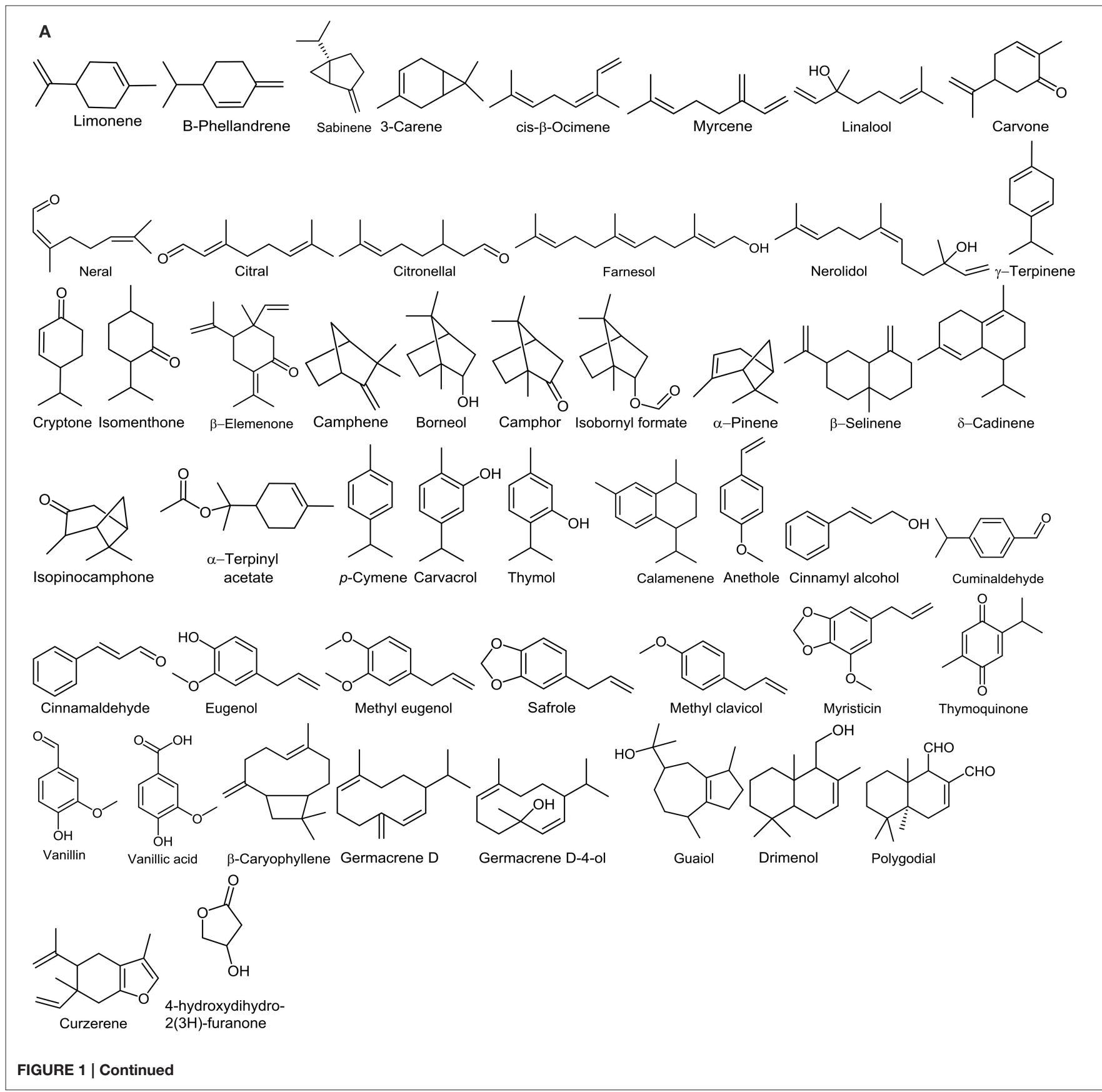




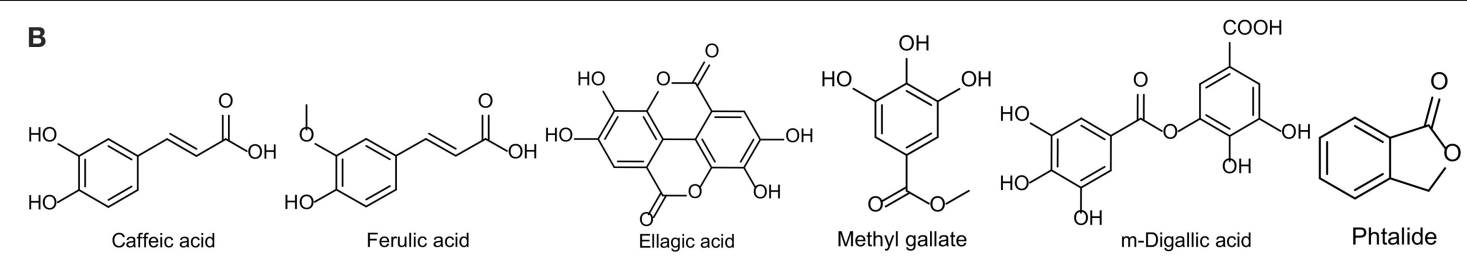
Lauric acid
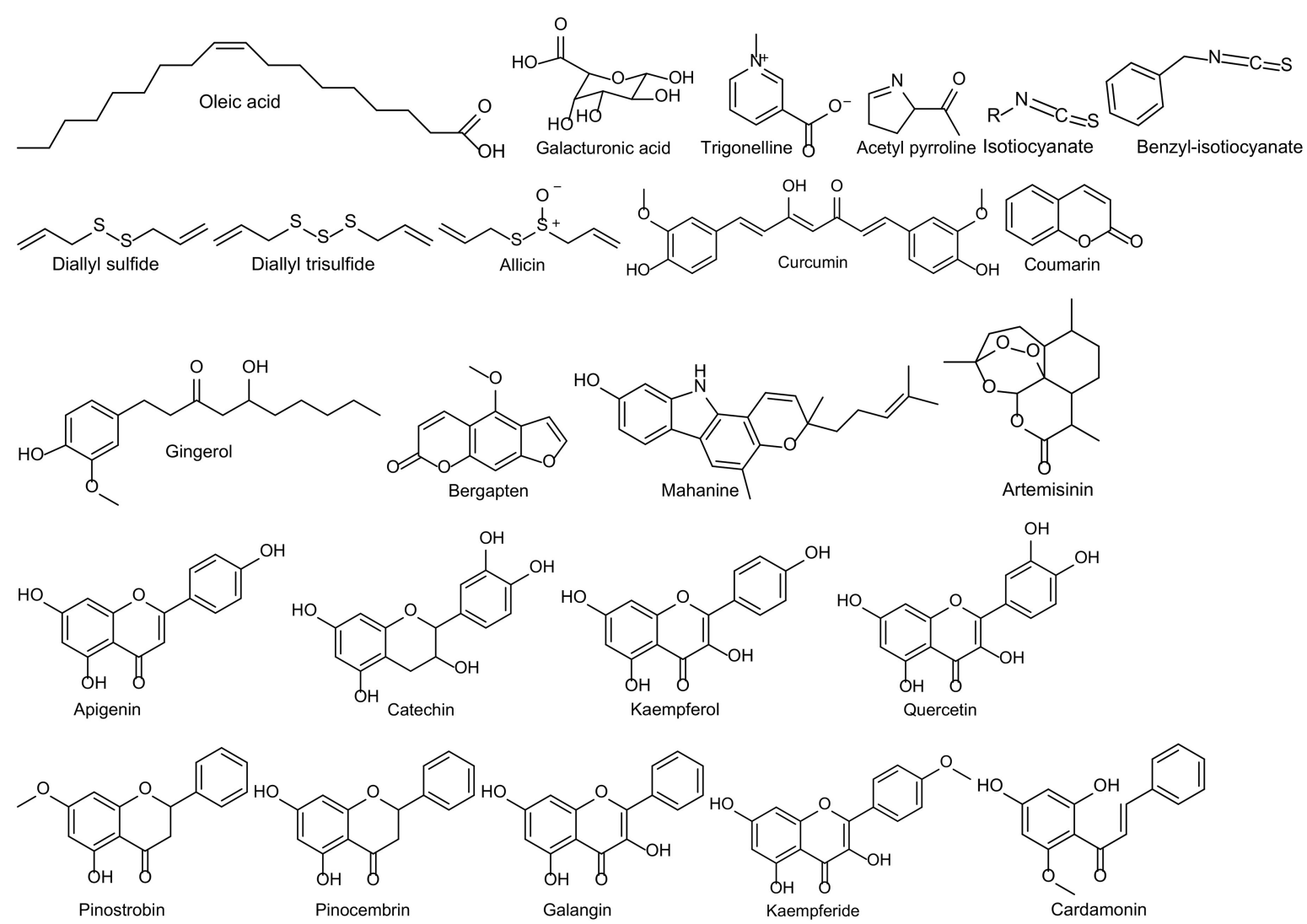<smiles>[Y]Oc1cc(O)c(CC=C(C)C)c(O)c1C(=O)/C=C/c1ccc(O)cc1</smiles><smiles></smiles>

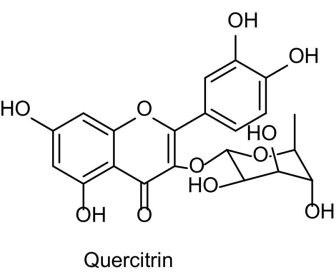<smiles>COc1cc(OC2OC3CCOC(CO)C(O)C(O)C3O2)cc2oc(-c3ccc(O)cc3)c(O)c(=O)c12</smiles>

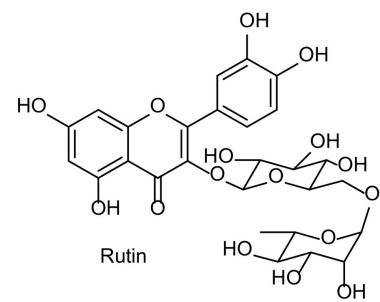

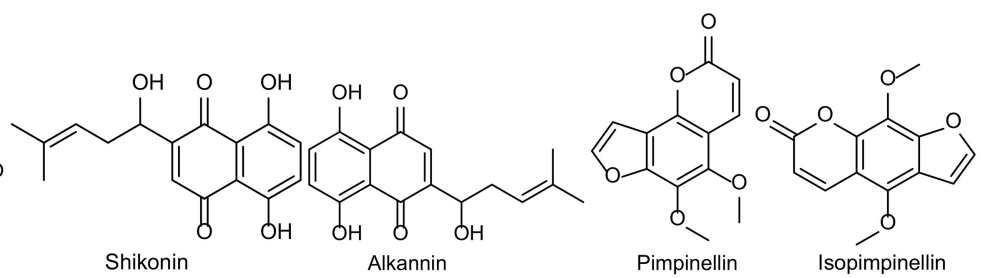


<smiles>COc1cc(O)c(C(=O)/C=C/c2ccccc2)c2c1C=CC(C)(CCC=C(C)C)O2</smiles>

Boesenbergin A<smiles>CCC(C=CC(C)C1CCC2C3CCC4CC(O)CCC4(C)C3CCC12C)C(C)C</smiles>

Stigmasterol<smiles>CCC(CCC(C)C1CCC2C3CCC4=CC(O)CCC4(C)C3CCC12C)C(C)C</smiles><smiles>COc1cc(CNC(=O)CCCC/C=C/C(C)C)ccc1O</smiles><smiles>CC(/C=C/C=C(\C)C(=O)O)=C\C=C\C=C(C)\C=C\C=C(/C)C(=O)O</smiles><smiles>C/C=C1\C(OC2C(O)C3OC(CO)C(O)C2O3)OC=C(C(=O)OC)C1CC(=O)OCCc1ccc(O)c(O)c1</smiles>

Crocetin

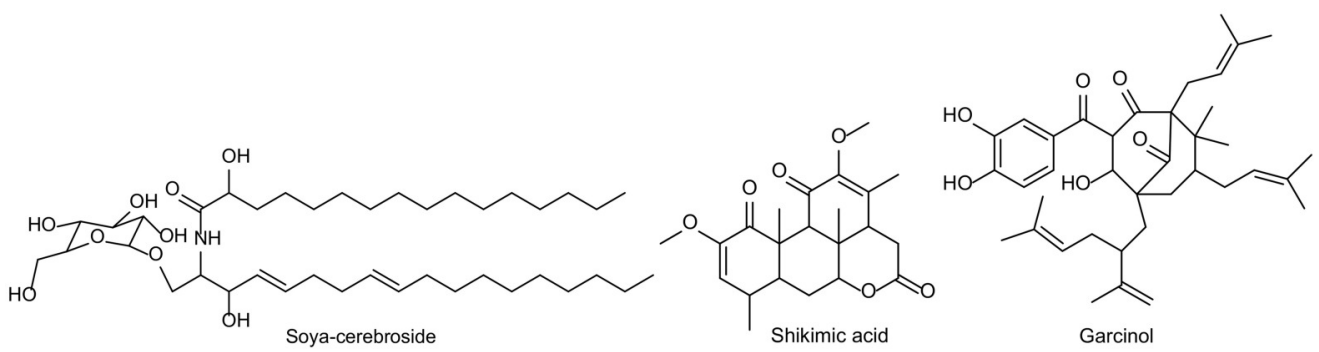

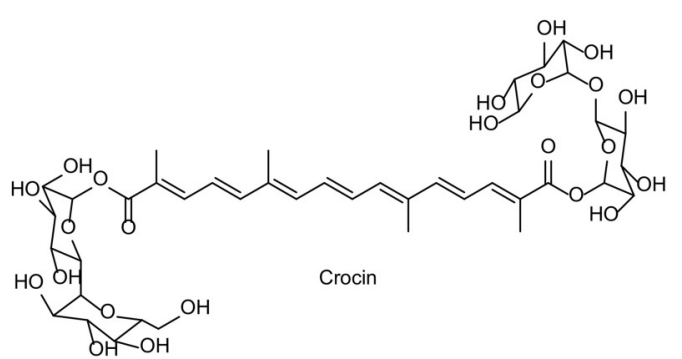

FIGURE 1 | Chemical structure of bioactive compounds of commonly used spices. (A) Volatile compounds; (B) Not volatile compounds.

active against Staphylococcus aureus and Bacillus subtilis (Shirazi et al., 2014). Essential oil of angelica roots were effective against Clostridium difficile, Cl. perfringens, Enterococcus faecalis, Eubacterium limosum, Peptostreptococcus anaerobius, and in a lower extent against E. coli and Bacteroides fragilis (Fraternale et al., 2014). Nigella sativa extracts were more effective on St. aureus (5th day inhibition zone $34 \mathrm{~mm}$ ) as compared to E. coli (5th day inhibition zone, $13 \mathrm{~mm}$ ) and $P$. aeruginosa (5th day inhibition zone, $30 \mathrm{~mm}$; Islam et al., 2012). Rosmarinus officinalis essential oil showed a strong antimicrobial effect against $L s$. monocytogenes and S. aureus compared with E. coli (Jordán et al., 2013). A list of spices and their effects on most relevant bacteria is reported in Table 1.

Spices, essential oils and extracts have also been known for their anti-fungal activity (Table 1; Tajkarimi et al., 2010). Huacatay and basil essential oils were active against Candida albicans (Shirazi et al., 2014). Radwan et al. (2014) reported that among 22 common spice extracts, turmeric, and nutmeg extracts were the most active against different plant pathogens belonging to the genus Colletotrichum. In another study, where 23 spice extracts were studied, Olax subscorpioidea extract showed the highest antifungal activity, particularly against $C$. albicans and C. tropicalis (Dzoyem et al., 2014). A reduction of mycelial growth and inhibition of conidial germination and aflatoxin production by A. flavus were described by Nerilo et al. (2016) when 150,10 and $15 \mu \mathrm{g} / \mathrm{mL}$ of ginger EO were applied, respectively. Ferreira et al. (2013) also reported a decrease (99.9 and $99.6 \%$ ) of aflatoxin B1 and B2 when $0.5 \%$ of turmeric EO was employed while the same EO completely inhibited the biomass of Fusarium graminearum and its zearalenone production, at 3.5 and $3 \mathrm{mg} / \mathrm{mL}$, respectively (Kumar et al., 2016).

Finally, antiviral activity of Mexican oregano against some viruses (i.e., acyclovir-resistant herpes simplex virus type 1 (ACVR-HHV-1), human respiratory syncytial virus (HRSV), and human rotavirus) has been reported (Pilau et al., 2011). Overall, it is difficult to predict how microorganisms are susceptible. In fact, spics constituents may impact several targets, such as microorganisms cell membrane, enzymes, and/or their genetic material (through the modulation of specific genes; Tajkarimi et al., 2010; Tyagi and Malik, 2010b,c; Hyldgaard et al., 2012). 


\section{Enhancement of the Antimicrobial Activity In vitro}

To enhance the antimicrobial potential of spices or their constituents, the use of mixed extracts or natural compounds having different origins have been reported (Bassolé and Juliani, 2012). In most of the cases spices showed synergistic activities/effects. For instance, the antimicrobial activity of basil, oregano, bergamot, and perilla essential oils alone or in combinations, were tested. Basil and oregano essential oils alone had MICs of 1.25 and $0.625 \mu \mathrm{L} / \mathrm{mL}$ against E. coli, respectively, while their values were $0.313 \mu \mathrm{L} / \mathrm{mL}$ when used in combination. The MIC values against St. aureus for basil and bergamot EOs alone were for both $1.25 \mu \mathrm{L} / \mathrm{mL}$, whereas the MICs of the two essential oils decreased to $0.313-0.156 \mu \mathrm{L} / \mathrm{mL}$ when combined, indicating higher antimicrobial activity. MICs of oregano and bergamot essential oils were 0.625 and $1.25 \mu \mathrm{L} / \mathrm{mL}$ against B. subtilis, respectively, whereas $0.313 \mu \mathrm{L} / \mathrm{mL}$ was determined for combined effect. Finally, the MIC values of oregano and perilla were $0.625 \mu \mathrm{L} / \mathrm{mL}$ for both against $S$. cerevisiae, while the mixture needed MICs of $0.313-0.156 \mu \mathrm{L} / \mathrm{mL}$ ( $\mathrm{Lv}$ et al., 2011). In another study, Tabanelli et al. (2014) demonstrated the additive effect of citral and linalool against $S$. cerevisiae. In fact, linalool $(250 \mathrm{mg} / \mathrm{L})$ reduced markedly the amount of citral needed for the same effect (from around 150 to $50 \mathrm{mg} / \mathrm{L}$ ). However, Tejeswini et al. (2014) reported antagonistic effects when cinnamaldehyde was combined with clove essential oils for molds inhibition.

The use of spice oils together with other preservation techniques has been also assessed. For example, low pressure atmosphere enhanced the susceptibility of E. coli and S. enteritidis to oregano, lemongrass or cinnamon essential oils in vitro. In particular, the MIC of cinnamon vapors for $S$. enteritidis decreased from 0.512 to $0.128 \mu \mathrm{L} / \mathrm{mL}$ (Frankova et al., 2014). Tabanelli et al. (2014) reported that the decrease of $\mathrm{a}_{w}$ potentiated the antimicrobial effect of citral (but not linalool) while lower $\mathrm{pH}$ favored the antimicrobial power of linalool (but not citral) against $S$. cerevisae. Some other hurdle technologies were also used for the enhancement of antimicrobial potential of essential oils. Tyagi and Malik (2010a, 2011, 2012) described the enhancement in antimicrobial potential of essential oils in combination of negative air ions (NAI) against food spoilage microorganisms.

\section{Antimicrobial Potential in Real Food Model System (In vivo)}

Numerous natural compounds of spices with defined antimicrobial properties have been isolated. However, in vitro studies represent only one part of the use of active compounds as preservatives in food. Moreover, their physical and biochemical properties have been changed in real food systems due to the complexity of the food matrices (Tajkarimi et al., 2010). Therefore, whether spices or their components have the potential to inhibit the food spoilage and act as a food preservative has been determined in different studies.

As summarized in Table 2, the use of spices as preservatives has been assessed in multiple foods: meat, fish, dairy products, vegetables, rice, fruit, and animal food (Tajkarimi et al., 2010;
Jayasena and Jo, 2013). Hernández-Ochoa et al. (2014) reported that cumin and clove essential oils inhibited the growth of total bacteria by $3.78 \log \mathrm{CFU} / \mathrm{g}$ when used on meat samples for 15 days at $2^{\circ} \mathrm{C}$. The antimicrobial activity of different spice extracts in raw chicken meat during storage for 15 days at $4^{\circ} \mathrm{C}$ was also studied. It has been found that the treatment of raw chicken meat with extracts of clove, oregano, cinnamon, and black mustard was effective against microbial growth (Radha et al., 2014). Essential oils of marjoram and coriander showed above $50 \%$ protection of chickpea seed from Aspergillus flavus infestation (Prakash et al., 2012). In an in vivo assay with cherry tomatoes (Lycopersicon esculentum), bay oil was effective against Alternaria alternata infection (Xu et al., 2014). In another experiment, Da Silveira et al. (2014) treated fresh Tuscan sausages with bay leaf essential oil. Comparing to the non-treated control, the essential oil was able to reduce the population of total coliforms (reduction of $2.8 \mathrm{log} \mathrm{CFU} / \mathrm{g}$ ) and extended the shelf life for 2 days. Rattanachaikunsopon and Phumkhachorn (2008) applied basil oil in nham, a fermented pork sausage, inoculated with $S$. enteritidis SE3 at $4^{\circ} \mathrm{C}$. Basil oil reduced the number of bacteria from 5 to $2 \log \mathrm{CFU} / \mathrm{g}$ after 3 days and the sensory evaluation suggested that these concentrations of oil were acceptable for the consumers. The isothiocyanates derived from oriental mustard reduced aflatoxins biosynthesis in A. parasiticus by $60.5-89.3 \%$ during Italian piadina storage (Saladino et al., 2016). Finally, Patrignani et al. (2015) reviewed the use of spices and their constituents in minimally processed fruits and vegetables.

Although several studies proved possible applications for spices and their derivatives as food preservatives, only few of them are currently applied on the market. For instance, rosemary is already employed for its preservative properties in meat products. Essential oil of rosemary has been used not only for its flavoring compounds but also for its antimicrobial and antioxidant activity. In fact, carnosic acid, one of its main component, is not only antimicrobial but it possesses an antioxidant activity higher than the common food additives, butylated hydroxytoluene (BHT), and butylated hydroxyanisole (BHA; De La Torre Torres et al., 2015).

Allyl isothiocyanate (AITC), a bioactive organosulfur compound found in cruciferous, plants, such as mustard, is known for its anticarcenogenic properties. It has been tested for effectiveness in preservation of fresh beef, sliced raw tuna and cheese. It possesses a strong antimicrobial activity against E. coli O157:H7, Salmonella enterica serovar Montevideo, S. enterica ser. Typhimurium, P. corrugata, Campylobacter jejuni, St. aureus, and Ls. monocytogenes. Moreover it has the generally recognized as safe (GRAS) status provided by the regulatory agencies of U.S. However, its application is sometimes limited because of its poor aqueous solubility, instability at high temperature, and susceptibility to degradation by nucleophilic molecules (Kim et al., 2002; Li et al., 2015).

\section{Enhancement of the Antimicrobial Activity In vivo}

Although some in vivo studies ended up with products acceptable for the consumers, the sensory aspect represents a critical point 
TABLE 2 | Antimicrobial potential of phytochemicals (spices) for food preservation; In vivo study.

Scientific/Common name
1. Allium sativum
2. Artemisia dracunculus
3. Boesenbergia rotunda
4. Brassica nigra
5. Cinnamomum verum
6. Citrus hystrix
7. Ceratonia siliqua
8. Coriandrum sativum
9. Cuminum cyminum

10. Cymbopogon citratus

11. Cinnamomum cassia

12. Eryngium foetidum

13. Laurus nobilis

14. Mentha piperita

15. Olea europaea

16. Origanum vulgare

17. Origanum majorana

18. Ocimum basilicum

19. Piper nigrum

20. Rosmarinus officinalis

21. Salvia officinalis

22. Satureja montana

\section{Real food models}

Prevent infections of $L$. acidophlus, E. coli

and Aer omonas hydrophila in poultry meat

Inhibit growth St. aureus and E. coli in cheese

Retard the growth of total viable counts of food pathogen

bacteria bacteria in Chinese sausage

Reduce microbial growth in raw chicken meat

Potential bio preservative of banana, vegetables, dairy products against Aspergillus spp., Salmonella spp.,

Inhibit the growth food pathogen bacteria in Chinese sausage

Inhibit the growth of Ls. monocytogenes in minced beef meat

Protection of chickpea seed from $A$. flavus infestation

Cumin seed oil protect stored protection of wheat

and chickpea against Aspergillus spp.

reduce total bacteria in meat samples

Inhibit the growth B. cereus, S. Typhimurium and St. au reus/

antibacterial agents in refrigerated chicken patties

control Ls. monocytogenes in bovine ground meat

inhibit microbial growth in real food system

Raw chicken meat

in Fresh sliced apples reduces natural microflora

and inoculated $L$ s. innocua

Reduce the growth of Ls. monocytogenes in pineapple juice

Bay essential oil reduce the population of total coliforms in fresh sausages

Protects cherry tomatoes against Alternaria alternata infection

Mentha essential oil inhibit $S$. cerevisiae growth in

fruit (orange/apple) juice-potential natural food preservative

Antibacterial effect against E. coli, $P$. aeruginosa, S. aureus and

K. pneumoniae in shrimp/seafood industry

Inhibit the growth of L. monocytogenes, Aeromonas hydrophila

and E. coli O157:H7 in meat, eggplant salad

inhibition of Pseudomonas spp. in rabbit meat

effectively inhibited the growth of Salmonella spp. in chicken meat

effective against microbial growth in raw chicken meat

in Fresh sliced apples reduces natural microflora and inoculated Ls. Innocua

Inhibit E coli O157:H7 in egg plant salad

inhibit Ls. monocytogenes, Y. enterocolitica, and A. hydrophilla in lceberg lettuce

control the natural microflora and inhibit Ls. monocytogenes,

\section{E. coli in Lamb's lettuce}

Protection of chickpea seed from A. flavus infestation

Inhibit the growth of $S$. enteritidis in fermented pork sausage

Oil and oleoresins control microbial growth in orange juice

Inhibit the growth of Ls. monocytogenes, Aeromonas hydrophila

and E. coli O157:H7 in meat

inhibition effect on Ls. monocytogenes in liver pork sausage

inhibit Ls. monocytogenes, Y. enterocolitica and A. Hydrophilla

in iceberg lettuce

Inhibit food spoilage in dairy products

and Salmonella spp. in minced beef meat

Control the growth of foodborne bacteria/improve quality of minced pork

\section{References}

Yadav and Singh, 2004

Raeisi et al., 2012

Kingchaiyaphum and Rachtanapun, 2012

Radha et al., 2014

Sessou et al., 2012

Kingchaiyaphum and Rachtanapun, 2012

Hsouna et al., 2011;

Prakash et al., 2012

Kedia et al., 2014

Hernández-Ochoa et al., 2014

Hayam et al., 2013

De Oliveira et al., 2013

Tyagi et al., 2013

Tyagi et al., 2014a

Radha et al., 2014

Patrignani et al., 2015

Ngang et al., 2014

Da Silveira et al., 2014

Xu et al., 2014

Tyagi et al., 2013

Ali et al., 2014

Tajkarimi et al., 2010

Tajkarimi et al., 2010

Burt, 2004

Jayasena and Jo, 2013

Radha et al., 2014

Patrignani et al., 2015

Patrignani et al., 2015

Patrignani et al., 2015

Patrignani et al., 2015

Prakash et al., 2012

Rattanachaikunsopon and Phumkhachorn, 2008

Kapoor et al., 2014

Tajkarimi et al., 2010

Tajkarimi et al., 2010

Patrignani et al., 2015

Tajkarimi et al., 2010

Hayouni et al., 2008

Tajkarimi et al., 2010

(Continued) 


\section{TABLE 2 | Continued}

\begin{tabular}{|c|c|c|}
\hline Scientific/Common name & Real food models & References \\
\hline \multirow[t]{4}{*}{ 23. Syzygium aromaticum } & Inhibit the growth of Ls. monocytogenes in mozzarella cheese, meat & Tajkarimi et al., 2010 \\
\hline & and bovine ground meat & De Oliveira et al., 2013 \\
\hline & reduced total bacteria in meat samples & Hernández-Ochoa et al., 2014 \\
\hline & effective against microbial growth in raw chicken meat & Radha et al., 2014 \\
\hline \multirow[t]{5}{*}{ 24. Thymus vulgaris } & Slight effect on Ps. putida in cooked shrimp sausages & Burt, 2004 \\
\hline & inhibit E. coli O157:H7 growth inhibition in lettuce and carrots & Patrignani et al., 2015 \\
\hline & and L. monocytogenes growth inhibition in minced pork & Burt, 2004 \\
\hline & control the natural microflora and inhibit Ls. monocytogenes, & Patrignani et al., 2015 \\
\hline & E. coli in lamb's lettuce & \\
\hline 25. Thymus capitatus & Ls. monocytogenes growth inhibition in minced beef meat & El Abed et al., 2014 \\
\hline 26. Zingiber officinale & Potential biopreservative of beverages against food spoiling yeasts and bacteria & Sessou et al., 2012 \\
\hline
\end{tabular}

in the use of spices and their active compounds in food. In fact, sometimes MIC values were three or four times higher than those estimated in vitro, have been applied to have a measurable or stable antimicrobial effect in vivo. This aspect can dramatically affect the physical characteristics and organoleptic properties of the food products. To overcome these issues, several strategies have been exploited for the enhancement of antimicrobial potential of spices in vivo.

The synergistic effect of spices together with their constituents or other natural products has been tested. Water extracts of clove, cinnamon, and oregano were applied, alone $(10 \mathrm{mg} / \mathrm{L})$ or in combination $(3.3 \mathrm{~g} / \mathrm{L}$ each), in raw chicken meat and several characteristics were followed during storage for 15 days at $4^{\circ} \mathrm{C}$. The mixture of the three extracts had the strongest impact on the bacterial load due to the synergistic actions of antimicrobial compounds present in the mixed spices (Radha et al., 2014). Siroli et al. (2014a) examined citral, carvacrol, citron essential oil, hexanal and 2-(E)-hexenal, alone $(250 \mathrm{mg} / \mathrm{L})$ or in combination $(125+125 \mathrm{mg} / \mathrm{L}$, except for the combination of citron essential oil/carvacrol, $200+50 \mathrm{mg} / \mathrm{L}$, respectively), to sanitize minimally processed apples. The treatment with citral/2-(E)-hexenal and hexanal/2-(E)-hexenal maintained a good retention of color parameter within the 35 days and there were no yeast spoilage in any treated sample. Gabriel and Pineda (2014) studied the effect of different concentrations of vanillin and licorice root extract (LRE) on the mild heat decimal reduction times (D55-values) of a cocktail of E. coli O157:H7 in young coconut liquid endosperm. They found that the combined effect was most significant only at concentrations above 250 and $210 \mathrm{mg} / \mathrm{L}$, respectively for vanillin and LRE. The efficacy of thymol $(0.1 \% \mathrm{w} / \mathrm{w})$ in combination with sodium lactate ( 1 and $2 \% \mathrm{v} / \mathrm{w})$ was evaluated in fish patty samples stored at $4{ }^{\circ} \mathrm{C}$ for 5 days. The presence of thymol plus $2 \%$ of sodium lactate had a synergetic effect against $S$. enterica ser. Typhimurium (Ilhak and Guran, 2014). Tejeswini et al. (2014) evaluated the antifungal activity of cinnamaldehyde, eugenol, peppermint, and clove essential oils and their combinations in tomato fruit system. While different concentrations of eugenol in combination with peppermint showed either additive or non-significant effect on mold inhibition, combination of cinnamaldehyde with clove essential oil produced nonsignificant or antagonist effects. Barbosa et al. (2014) also assessed the impact of basil essential oil alone or in combination with sodium hexametaphosphate (SHMP), on the shelf life of chicken sausage. Concentrations of 0.3 or $0.03 \%$ of essential oil inhibited the coliforms for 15 days at $4^{\circ} \mathrm{C}(P<0.05)$. On the contrary, this effect was inhibited when SHMP was combined.

The synergistic effect of spices on other food preservation systems, such as mild thermal processing, has been also explored. Ngang et al. (2014) studied how to reduce the thermal impact during juice production. They demonstrated that pasteurizing pineapple juice at $60^{\circ} \mathrm{C}$ in presence of long coriander essential oil, lowered the time required for a $97 \%$ reduction of $L s$. monocytogenes compared with treatment without essential oil. Similarly, mint, lemon grass, or eucalyptus essential oils worked synergistically with mild thermal treatment to inhibit the microbial growth in real food systems. Therefore, subsequent lower doses of oils were required for the food preservation (Tyagi et al., 2013, 2014a,b).

The use of spices together with additional high tech/cuttingedge technologies has also been studied. Pina-Pérez et al. (2012) demonstrated the applicability of Pulsed Electric Fields $(\mathrm{PEF})$ in combination with cinnamon against $S$. enterica ser. Typhimurium to enhance the safety of dairy beverages. The maximum synergistic effect was achieved by $10 \mathrm{kV} / \mathrm{cm}-$ $3000 \mu \mathrm{s}$ PEF treatment with $5 \%(\mathrm{w} / \mathrm{v})$ cinnamon. The maximum inactivation level (1.97 $\log _{10}$ cycles) was achieved at 30 $\mathrm{kV} / \mathrm{cm}-700 \mu \mathrm{s}$ plus $5 \%$ cinnamon. Patrignani et al. (2013) enhanced the effect of high-pressure homogenization (HPH) treatment (100 MPa for 1-8 successive passes) with citral into inoculated apricot juices, extending their shelf life in turn. Abriouel et al. (2014), instead, potentiated the effect of high hydrostatic pressure (HHP) on brined olives using thyme and rosemary essential oils. In other cases, novel technologies have been used to preserve the functional compounds. For instance, the use of AITC can be limited by its poor aqueous solubility, degradation by nucleophilic molecules, high volatility, and strong odor. Koa et al. (2012) masked the odor and volatility of AITC through its microencapsulation with Arabic 
gum and chitosan. In addition, Li et al. (2015) developed nanoemulsions that allowed a better aqueous solubility and chemical stability. Eventually, new packaging systems (active packaging) have been studied where essential oils or their main compounds were incorporated into the films. However, until now the research did not provide consistent results (Maisanaba et al., 2016). All these studies showed that the antimicrobial and food preservative potential of natural compounds can be enhanced or maintained by applying physical technologies.

\section{MODE OF ANTIMICROBIAL ACTION OF SPICES}

Although the antimicrobial effects of spices and their derivates have been tested against a wide range of microorganisms over the years, their mode of action is still not completely understood. In fact, spices and their essential oils can contain many different bioactive compounds present in variable amounts. Basically, the bioactive constituents of spices can be divided into volatile and non-volatile compounds (Figures 1A,B). The first ones are mainly responsible for the antimicrobial activity of spices. They can be divided in four groups: terpens, terpenoids, phenylpropenes, and "others" (such as products of degradation; Hyldgaard et al., 2012). Terpens are evaluated as lesser active antimicrobial compounds amongst the other compounds. For instance, the weak activity of $\rho$-cymene, one of the main component of thyme, is mainly related to its action as a substitutional membrane impurity. It can affect the melting temperature and the membrane potential, which in turn causes a decrease in cell motility (Hyldgaard et al., 2012). On the other hand, terpenoids, such as the well-studied thymol and carvacrol, exert their antimicrobial activity due to their functional groups (hydroxyl groups and delocalized electrons). For instance, thymol can interact with the membrane both with the polar head-group region of the lipid layer, affecting the permeability, or with the proteins, determining an accumulation of misfolded structures (Hyldgaard et al., 2012; Marchese et al., 2016). These changes can lead to cell leakages that in turn can bring the cell to death (O'Bryan et al., 2015). Once it is inside the cells, thymol can also disrupt important energy-generating processes such as the citrate metabolic pathway and the synthesis of ATP (Hyldgaard et al., 2012; O’Bryan et al., 2015). Carvacrol acts mainly at the level of the membrane as a transmembrane carrier of monovalent cations, exchanging $\mathrm{K}+$ with $\mathrm{H}+$ in the cytoplasm (O'Bryan et al., 2015). Other organic compounds present in spices are phenylpropenes, such as eugenol and cinnamaldhehyde. The antimicrobial activity of eugenol is performed mainly at the level of the membranes and proteins, inducing permeabilization and enzyme inactivation. On the contrary cinnamaldheyde, although less powerful than eugenol, can react and cross-link with DNA and proteins other than interact with cell membranes. Eventually, spices possess other degradation compounds originating from unsaturated fatty acids, lactones, terpenes, glycosides, and sulfur- and nitrogen-containing molecues. For instance, the mode of action of AITC, a nitrogen-containing compound, is generally considered as a non-specific inhibition of periplasmic or intracellular targets. In fact, due to its highly electrophile central carbon atom, it can inhibit enzymes and affect proteins by oxidative cleavage of disulfide bonds (Hyldgaard et al., 2012). AITC is the main constituent of mustard essential oil. Clemente et al. (2016) reported that mustard EO induced cell cycle arrest, resulting in bacterial filamentation.

Other than affecting membrane and intracellular stability, Szabo et al. (2010) reported that clove, oregano, lavender, and rosemary essential oils possess quorum sensing inhibitory activity. For instance, molecules such as furanones can be internalized by bacteria, bind to LuxR-type proteins, and destabilize them (Camilli and Bassler, 2006). In this way spices could impact the motility, swarming, and biofilm production of bacteria. Overall, antimicrobial activity of spices cannot be confirmed based only on the action of one compound. The final activity is a synergistic effect of more components.

\section{CONCLUSION}

Starting from the food preparation, spices can affect both food spoilage microorganisms (food preservation) and human pathogens (food safety) due to the antimicrobial and antifugal activity of their natural constituents. Spices are provided from natural herbs and plants and generally recognized as safe (GRAS) by the American Food and Drug Administration (FDA). However, the need of high amount of natural compounds represent the main limitation for effective performance against microorganisms. Mostly, their organoleptic characteristics may impact the results of in vitro and in vivo trials. For this reason, combinations of spices or their pure natural compounds, applied with or without additional technologies, represent a promising alternative to avoid this problem. Synergistic effects can lead to a reduction of both natural compounds used and treatment applied. In several cases, additive activities have been also reported. The study of spices, natural compounds, and novel combination technologies can be source of inspiration for developing novel or enhanced molecules acting against spoilage microorganisms.

\section{AUTHOR CONTRIBUTIONS}

DG: Data compilation, manuscript writing, DB: Data compilation, table formation, SP: Data compilation, manuscript writing, and formating, AT: Data compilation, manuscript writing, editing and formatting, and final approval.

\section{ACKNOWLEDGMENTS}

We thank Prof. V. Craig Jordan (Father of Tamoxifen) for providing the facility to revise the manuscript. This research was supported by a grant from the Ministry of Education, Science and Technological Development of Serbia (Project No. 173029). 


\section{REFERENCES}

Abriouel, H., Benomar, N., Gálvez, A., and Pulido, P. R. (2014). Preservation of Manzanilla alore-a cracked green table olives by high hydrostatic pressure treatments singly or in combination with natural antimicrobials. LWT Food Sci. Technol. 56, 427-431. doi: 10.1016/j.lwt.2013.09.012

Agrahari, P., and Singh, D. K. (2014). A review on the pharmacological aspects of Carum carvi. J. Biol. Earth Sci. 4, M1-M13.

Ajaiyeoba, E. O., and Krebs, H. C. (2003). Antibacterial and antifungal activities of Quassia undulate and Quassia amara extracts in vitro. Afr. J. Med. Sci. 32, 353-356.

Al-Dhubiab, B. E. (2012). Pharmaceutical applications and phytochemical profile of Cinnamomum burmannii. Pharmacogn. Rev. 6, 125-131. doi: 10.4103/09737847.99946

Ali, M. A., Rabii, N. S., Garbaj, M. A., and Abolghait, S. K. (2014). Antibacterial effect of olive (Olea europaea L.) leaves extract in raw peeled undeveined shrimp (Penaeus semisulcatus). Int. J. Vet. Sci. Med. 2, 53-56. doi: 10.1016/j.ijvsm.2014.04.002

Al-Qudah, M. A., Al-Jaber, H. I., Muhaidat, R., Hussein, E. I., Abdel, A. A., Hamid, Al-Smadi, M. L., et al. (2011). Chemical composition and antimicrobial activity of the essential oil from Sinapis alba L. and Sinapis arvensis L. (Brassicaceae) growing wild in Jordan. Res. J. Pharm. Biol. Chem. Sci. 2, 1136-1144.

Alves-Silva, J. M., Dias dos Santos, S. M., Pintado, M. E., Pérez-Álvarez, J. A., Fernández-López, J., and Viuda-Martos, M. (2013). Chemical composition and in vitro antimicrobial, antifungal and antioxidant properties of essential oils obtained from some herbs widely used in Portugal. Food Control 32, 371-378. doi: 10.1016/j.foodcont.2012.12.022

Amensour, M., Bouhdid, S., Fernandez-Lopez, J., Idaomar, M., Senhaji, S. N., and Jamal Abrini, J. (2010). Antibacterial activity of extracts of Myrtus communis against food-borne pathogenic and spoilage bacteria. Int. J. Food Proper. 13, 1215-1224. doi: 10.1080/10942910903013399

Anuradha, M., Pragyandip, D., Murthy, P. N., Siddique, H. H., and Kushwaha Poonam, A. (2012). Classical review on Rajika (Brassica juncea). Res. Rev. J. Bot. Sci. 1, 18-23.

Baananou, S., Bouftira, I., Mahmoud, A., Boukef, K., Marongiu, B., and Boughattas, N. A. (2013). Antiulcerogenic and antibacterial activities of Apium graveolens essential oil and extract. Nat. Prod. Res. 27, 1075-1083. doi: 10.1080/14786419.2012.717284

Bansode, V. J. (2012). A review on pharmacological activities of Cinnamomum cassia Blume. Int. J. Green Pharm. 6, 102-108. doi: 10.4103/0973-8258. 102823

Barbosa, L. N., Alves, F. C., Andrade, B. F., Albano, M., Castilho, I. G., Rall, V. L., et al. (2014). Effects of Ocimum basilicum Linn essential oil and sodium hexametaphosphate on the shelf life of fresh chicken sausage. J. Food Prot. 6, 872-1042. doi: 10.4315/0362-028x.jfp-13-498

Barbosa, Q. P. S., da Câmara, C. A. G., Ramos, C. S., Nascimento, D. C. O., LimaFilho, J. V., and Guimarães, E. F. (2012). Chemical composition, circadian rhythm and antibacterial activity of essential oils of Piper divaricatum: a new source of safrole. Quím. Nova 35, 1806-1808. doi: 10.1590/S010040422012000900019

Bassolé, I. H. N., and Juliani, H. R. (2012). Essential oils in combination and their antimicrobial properties. Molecules 17, 3989-4006. doi: 10.3390/molecules 17043989

Bhargava, V. K. (2011). Medicinal uses and pharmacological properties of Crocus sativus Linn (Saffron). Int. J. Pharm. Pharm. Sci. 3, 975-1491.

Bharti, P., Sheema Bai, S., Seasotiya, L., Malik, A., and Dalal, S. (2012). Antibacterial activity and chemical composition of essential oils of ten aromatic plants against selected bacteria. Int. J. Drug Dev. Res. 4, 342-351.

Bhatia, M., and Sharma, A. (2012). Inhibitory activities of Brassica nigra, Cinnamomum cassia (Blume) and Cuminum cyminum towards Escherichia coli and Staphylococcus aureus. Arch. Appl. Sci. Res. 4, 1811-1815.

Bhatt, R. M., Juyal, V., and Singh, A. (2014). Amomum subulatum Roxb: a critical review of pharmacological and phytochemical data. Int. J. Pharm. Phytopharm. 3, 362-364.

Boubaker, E. R., Akkari, H., Bchir, F., Gharbi, M., Mhadhbi, M., Awadi, S., et al. (2013). Thymus capitatus from Tunisian arid zone: chemical composition and in vitro anthelmintic effects on Haemonchus contortus. Vet. Parasitol. 197, 374-378. doi: 10.1016/j.vetpar.2013.05.016
Bounatirou, S., Smiti, S., Miguel, M. G., Faleiro, L., Rejeb, M. N., Neffati, M., et al. (2007). Chemical composition, antioxidant and antibacterial activities of the essential oils isolated from Tunisian Thymus capitatus Hoff. et Link. Food Chem. 105, 146-155. doi: 10.1016/j.foodchem.2007.03.059

Burt, S. (2004). Essential oils: their antibacterial properties and potential applications in foods - a review. Int. J. Food Microbiol. 94, 223-253. doi: 10.1016/j.ijfoodmicro.2004.03.022

Cachet, N., Hoakwie, F., Bertani, S., Bourdy, G., Deharo, E., Stien, D., et al. (2009). Antimalarial activity of simalikalactone E, a new quassinoid from Quassia amara L. (Simaroubaceae). Antimicrob. Agents Chemother. 53, 4393-4398. doi: 10.1128/AAC.00951-09

Camilli, A., and Bassler, B. L. (2006). Bacterial small-molecule signaling pathways. Science 311, 1113-1116. doi: 10.1126/science.1121357

Carraminana, J. J., Rota, C., Burillo, J., and Herrera, A. (2008). Antibacterial efficiency of spanish Satureja montana essential oil against Listeria monocytogenes among natural flora in minced pork. J. Food Protect. 71, 502-508.

Carvalho, M. G., Melo, A. G. N., Aragão, C. F. S., Raffin, F. N., and Moura, T. F. A. L. (2013). Schinus terebinthifolius Raddi: chemical composition, biological properties and toxicity. Rev. Bras. Plantas Med. 15, 158-169. doi: 10.1590/s1516-05722013000100022

Cavanagh, H. M. A., and Wilkinson, J. M. (2005). Lavender essential oil: a review healthcare infection. Aust. Infect. Control 10, 35-37. doi: 10.1071/ HI05035

Ceylan, E., and Fung, D. Y. C. (2004). Antimicrobial activity of spices. J. Rapid Meth. Aut. Mic. 12, 1-55. doi: 10.1111/j.1745-4581.2004.tb00046.x

Chauhan, B., Kumar, G., and Ali, M. (2012). A review on phytochemical constituents and activities of Trachyspermum ammi sprague fruits. Am. J. Pharm. Tech. Res. 2, 330-340.

Cherrat, L., Espina, L., Bakkali, M., García-Gonzalo, D., Pagán, R., and Laglaoui, A. (2014). Chemical composition and antioxidant properties of Laurus nobilis L. and Myrtus communis L. essential oils from Morocco and evaluation of their antimicrobial activity acting alone or in combined processes for food preservation. J. Sci. Food Agr. 94, 1197-1204. doi: 10.1002/jsfa.6397

Ciesarová, Z., Suhaj, M., and Horváthová, J. (2008). Correlation between acrylamide contents and antioxidant capacities of spice extracts in a model potato matrix. J. Food Nutr. Res. 47, 1-5.

Clemente, I., Aznar, M., Silva, F., and Nerín, C. (2016). Antimicrobial properties and mode of action of mustard and cinnamon essential oils and their combination against foodborne bacteriaInnov. Food Sci. Emerg. 36, 26-33. doi: 10.1016/j.ifset.2016.05.013

Cock, I. E. (2013). The phytochemistry and chemotherapeutic potential of Tasmannia lanceolata (Tasmanian pepper). A review. Phcog. Commn. 3, 1-13. doi: 10.5530/pc.2013.2.1

Da Silveira, S. M., Luciano, F. B., Fronza, N., Cunha, A., Scheuermann, G. N., and Vieira, C. R. W. (2014). Chemical composition and antibacterial activity of Laurus nobilis essential oil towards foodborne pathogens and its application in fresh Tuscan sausage stored at $7^{\circ} \mathrm{C}$. LWT Food Sci. Technol. 59, 86-93. doi: 10.1016/j.lwt.2014.05.032

Degaspari, C. H., Waszczynsky, N., and Prado, M. R. M. (2005). Atividade antimicrobiana de Schinus terebinthifolius Raddi. Ciências Agrotecnologia 29, 617-622. doi: 10.1590/S1413-70542005000300016

De La Torre Torres, J. E., Gassara, F., Kouassi, A. P., Kaur Brar, S., and Belkacemi, K. (2015). Spice use in food: properties and benefits. Crit. Rev. Food Sci. Nutr. doi: 10.1080/10408398.2013.858235. [Epub ahead of print].

De Martino, L., Iorio, M., Coppola, G., Campana, A., Savastano, C., Fusco, B. M., et al. (2008). Verbena officinalis essential oil as apoptotic inductor in leukocytes of healthy subjects and chronic myeloid leukemic patients. Pharmacology 2, $170-175$.

De Oliveira, T. L. C., das Graças Cardoso, M., de Araújo Soares, R., Ramos, E. M., Piccoli, R. H., and Tebaldi, V. M. (2013). Inhibitory activity of Syzygium aromaticum and Cymbopogon citratus (DC.) Stapf. essential oils against Listeria monocytogenes inoculated in bovine ground meat. Braz. J. Microbiol. 44, 357-365. doi: 10.1590/S1517-83822013005000040

Di Pasqua, R., de Feo, V., Villani, F., and Mauriello, G. (2005). In vitro antibacterial activity of essential oil from Mediterranean Apiaceae, Verbenaceae and Lamiaceae against foodborne pathogens and spoilage bacteria. Ann. Microbiol. $55,139-143$. 
Divya, K., Ramalakshmi, K., Murthy, P. S., and Mohan Rao, J. L. (2014). Volatile oils from Ferula asafoetida varieties and their antimicrobial activity. LWT Food Sci. Technol. 59, 774-779. doi: 10.1016/j.lwt.2014.07.013

Doherty, V. F., Olaniran, O. O., and Kanife, U. C. (2010). Antimicrobial activities of Aframomum melegueta (Alligator pepper). Int. J. Biol. 2, 126-131. doi: 10.5539/ijb.v2n2p126

Dzoyem, J. P., Tchuenguem, R. T., Kuiate, J. R., Teke, G. N., Kechia, F. A., and Kuete, V. (2014). In vitro and in vivo antifungal activities of selected Cameroonian dietary spices. BMC Complement. Altern. Med. 14:58. doi: 10.1186/1472-6882-14-58

El, S. N., and Karakaya, S. (2009). Olive tree (Olea europaea) leaves: potential beneficial effects on human health. Nutr. Rev. 67, 632-638. doi: 10.1111/j.17534887.2009.00248.x

El Abed, N., Kaabi, B., Smaali, I. M., Chabbouh, M., Habibi, K., Marzouki, M. N., et al. (2014). Chemical composition, antioxidant and antimicrobial activities of Thymus capitata essential oil with its preservative effect against Listeria monocytogenes inoculated in minced beef meat. J. Evid. Based Complement. Altern. Med. 2014:152487. doi: 10.1155/2014/152487

Elhassan, I. A., Elamin, E. E., Mohamed, S., and Ayoub, H., (2010). Chemical composition of essential oil in dried fruits of Xylopia aethiopica from Sudan. J. Med. Aromatic Plants 1, 24-28.

Elumalai, A., and Eswaraiah, M. C. (2011). A pharmacological review on Garcinia indica Choisy. Int. J. Univers. Pharm. Life Sci. 1, 508-206.

Eng-Chong, T., Yean-Kee, L., Chin-Fei, C., Choon-Han, H., Sher-Ming, W., Thio Li-Ping, C., et al. (2012). Boesenbergia rotunda: from ethnomedicine to drug discovery. J. Evid. Based Complem. Altern. Med. 2012:473637. doi: 10.1155/ 2012/473637

Esmaeili, A., Masoudi, S., Masnabadi, N., and Rustaiyan, A. H. (2010). Chemical constituents of the essential oil of Sanguisorba minor Scop. leaves, from Iran. J. Med. Plants 9, 67-70.

Eyob, S., Martinsen, B. K., Tsegaye, A., Appelgren, M., and Skrede, G. (2008). Antioxidant and antimicrobial activities of extract and essential oil of korarima (Aframomum corrorima (Braun) P. C. M. Jansen). Afr. J. Biotechnol. 7, 2585-2592. Available online at: http://www.academicjournals.org/AJB

Faiza, I., Kholkhal, W., Gaouar, N., Bekhechi, C., and Bekkara Fawzia, A. (2011). Antibacterial and antifungal activities of olive (Olea europaea L.) from Algeria. J. Microbiol. Biotechnol. Res. 1, 69-73.

Faras, A. F., Wadkar, S. S., and Ghosh, J. S. (2014). Effect of leaf extract of Pandanus amaryllifolius (Roxb.) on growth of Escherichia coli and Micrococcus (Staphylococcus) aureus. Int. Food Res. J. 21, 421-423.

Ferreira, F. D., Kemmelmeier, C., Arrotéia, C. C., da Costa, C. L., Mallmann, C. A., Janeiro, V., et al. (2013). Inhibitory effect of the essential oil of Curcuma longa L. and curcumin on aflatoxin production by Aspergillus flavus Link. Food Chem. 136, 789-793. doi: 10.1016/j.foodchem.2012.08.003

Fitzgerald, D. J., Stratford, M., and Narbad, A. (2003). Analysis of the inhibition of food spoilage yeasts by vanillin. Int. J. Food Microbiol. 86, 113-122. doi: 10.,1016/S0168-1605(03)00059-X

Fleischer, T. C., Mensah, M. L. K., Mensah, A. Y., Komlaga, G., Gbedema, S. Y., and Skaltsa, H. (2008). Antimicrobial activity of essential oils of Xylopia aethiopica. Afr. J. Tradit. Complement. Altern. Med. 5, 391-393. doi: 10.4314/ajtcam.v5i4.31295

Folashade, K. O., and Egharevba, H. O. (2012). Essential oil of Lippia multiflora moldenke: a review. J. Appl. Pharm. Sci. 2, 15-23.

Frankova, A., Smid, J., Kloucek, P., and Pulkrabek, J. (2014). Enhanced antibacterial effectiveness of essential oils vapors in low pressure environment. Food Control 35, 14-17. doi: 10.1016/j.foodcont.2013.06.033

Fraternale, D., Flamini, G., and Ricci, D. (2014). Essential oil composition and antimicrobial activity of Angelica archangelica L. (Apiaceae) roots. J. Med. Food. 17, 1043-1047. doi: 10.1089/jmf.2013.0012

Gabriel, A. A., and Pineda, J. K. F. (2014). Influences of vanillin and licorice root extract supplementations on the decimal reduction times of Escherichia coli O157:H7 in mildly heated young coconut liquid endosperm. Food Control 38, 136-141. doi: 10.1016/j.foodcont.2013.10.011

Ghderi, P., Ahmadi, R., Balkanyian, F., Moridikyia, A., Mahdavi, E., and Tavakoli, P. (2014). "In vitro antibacterial activity of Bunium persicum and Mentha longifolia against Bacillus subtilis and Staphylococcus aureus," in International Conference on Chemical, Agricultural and Medical Sciences (CAMS-2014) May 2-3 (Antalya).
Ghosh, A. K., Banerjee, S., Mullick, H. I., and Banerjee, J. (2011). Zingiber officinale: a natural gold. Int. J. Pharm. Bio Sci. 2, 283-294.

Gong, Y. W., Huang, Y. F., Zhou, L. G., and Jianf, W. (2009). Chemical composition and antifungal activity of the fruit oil of Zanthoxylum bungeanum Maxim. (Rutaceae) from China. J. Ess. Oil Res. 21, 174-178. doi: 10.1080/10412905.2009.9700141

Gorai, D., Jash, K. S., Singh, R. K., and Gangopadhyay, A. (2014). Chemical and pharmacological aspects of Limnophila aromatica (Scrophulariaceae): an overview. Am. J. Phytomed. Clin. Ther. 2, 348-356.

Gulfraz, M., Sadiq, A., Tariq, H., Imran, M., Qureshiand, R., and Zeenat, A. (2011). Phytochemical analysis and antibacterial activity of Eruca sativa seed. Pak. J. Bot. 43, 1351-1359.

Gupta, A. D., Bansal, V. K., Babu, V., and Maithil, N. (2013b). Chemistry, antioxidant and antimicrobial potential of nutmeg (Myristica fragrans Houtt) J. Genet. Eng. Biotechnol. 11, 25-31. doi: 10.1016/j.jgeb.2012.12.001

Gupta, S. C., Sung, B., Kim, J. H., Prasad, S., Li, S., and Aggarwal, B. B. (2013a). Multitargeting by turmeric, the golden spice: from kitchen to clinic. Mol. Nutr. Food Res. 57, 1510-1528. doi: 10.1002/mnfr.201100741

Gutierrez, J., and Barry-Ryan, C., and Bourke, P. (2009). Antimicrobial activity of plant essential oils using food model media: efficacy, synergistic potential and interaction with food components. Food Microbiol. 26, 142-150. doi: 10.1016/j.fm.2008.10.008

Haidaria, F., Keshavarzb, S. A., Shahia, M. M., Mahboobc, S.-A., and Rashidid, M. R. (2011). Effects of parsley (Petroselinum crispum) and its flavonol constituents, kaempferol and quercetin, on serum uric acid levels, biomarkers of oxidative stress and liver xanthine oxidoreductase activity in oxonateinduced hyperuricemic rats. Iran. J. Pharm. Res.10, 811-819.

Hamad, M. N. (2012). Isolation of rutin from Ruta graveolens (Rutaceae) cultivated in Iraq by precipitation and fractional solubilisation. Pharmacie Globale 3, 1-3.

Handral, H. K., Pandith, A., and Shruthi, S. D. (2012). A review on Murraya koenigii: multipotential medicinal plant. Asian J. Pharm. Clin. Res. 5, 5-14.

Hayam, M., Ibrahim, Ferial, M., and Abu, S. (2013). Effect of adding lemongrass and lime peel extracts on chicken patties quality. J. Appl. Sci. Res. 9, 5035-5047.

Hayouni, E. A., Chraief, I., Abedrabba, M., Bouix, M., Leveau, J. Y., Mohammed, H., et al. (2008). Tunisian Salvia officinalis L. and Schinus molle L. essential oils: their chemical compositions and their preservative effects against Salmonella inoculated in minced beef meat. Int. J. Food Microbiol. 125, 242-251. doi: 10.1016/j.ijfoodmicro.2008.04.005

Hemati, A., Azarnia, M., and Angaji, S. A. (2010). Medicinal effects of Heracleum persicum (Golpar). Middle East J. Sci. Res. 5, 17-176.

Hernández-Hernández, E., Regalado-González, C., Vázquez-Landaverde, P., Guerrero-Legarreta, I., and García-Almendárez, B. E. (2014). Microencapsulation, chemical characterization, and antimicrobial activity of Mexican (Lippia graveolens H.B.K.) and European (Origanum vulgare L.) oregano essential oils. Sci. World J. 2014:641814. doi: 10.1155/2014/ 641814

Hoque, M. M., Rattila, S., Shishir, M. A., Bari, M. L., Inatsu, Y., and Kawamoto, S. (2011). Antibacterial activity of ethanol extract of betel leaf (Piper betle L.) against some food borne pathogens. Bangladesh J. Microbiol. 28, 58-63. doi: 10.3329/bjm.v28i2.11817

Hernández-Ochoa, L., Aguirre-Prieto, Y. B., Nevárez-Moorillón, G. V., GutierrezMendez, N., and Salas-Mu-oz, E. (2014). Use of essential oils and extracts from spices in meat protection. J. Food Sci. Technol. 51, 957-963. doi: 10.1007/s13197-011-0598-3

Hsouna, A. B., Trigui, M., Mansour, R. B., Jarraya, R. M., Damak, M., and Jaoua, S. (2011). Chemical composition, cytotoxicity effect and antimicrobial activity of Ceratonia siliqua essential oil with preservative effects against Listeria inoculated in minced beef meat. Int. J. Food Microbiol. 148, 66-72. doi: 10.1016/j.ijfoodmicro.2011.04.028

Hu, Y. M., Ye, W. C., Yin, Z. Q., and Zhao, S. X. (2007). Chemical constituents from flos Sesamum indicum L. Yao Xue Xue Bao 42, 286-291.

Hyldgaard, M., Mygind, T., and Meyer, R. L. (2012). Essential oils in food preservation: mode of action, synergies, and interactions with food matrix components. Front. Microbiol. 3:12. doi: 10.3389/fmicb.2012. 00012

Hymete, A., Rohloff, J., and Iversen, T. H. (2006). Essential oil from seeds and husks of Aframomum corrorima from Ethiopia. Flavour Frag. J. 21, 642-644. doi: $10.1002 / \mathrm{ffj} .1634$ 
Ilhak, O. I., and Guran, H. S. (2014). Combined antimicrobial effect of thymol and sodium lactate against Listeria monocytogenes and Salmonella Typhimurium in fish Patty. J. Food Saf. 34, 201-217. doi: 10.1111/jfs.12115

Islam, M. H., Ahmad, I. Z., and Salman, M. T. (2012). Antibacterial activity of Nigella sativa seed in various germination phases on clinical bacterial strains isolated from human patients. J. Biotechnol. Pharm. Res. 4, 8-13.

Jayasena, D. D., and Jo, C. (2013). Essential oils as potential antimicrobial agents in meat and meat products: a review. Trends Food Sci. Technol. 34, 96-108. doi: 10.1016/j.tifs.2013.09.002

Jirovetz, L., Buchbauer, G., Stoyanova, A. S., Evgenii, V., Georgiev, V., and Damianova, S. T. (2005). Composition, quality control and antimicrobial activity of the essential oil of cumin (Cuminum cyminum L.) seeds from Bulgaria that had been stored for up to 36 years. Food Sci. Technol. 40, 305-310. doi: 10.1111/j.1365-2621.2004.00915.x

Jordán, M. J., Lax, V., Rota, M. C., Lorán, S., and Sotomayor, J. A. (2013). Effect of bioclimatic area on the essential oil composition and antibacterial activity of Rosmarinus officinalis L. Food Control 30, 463-468. doi: 10.1016/j.foodcont.2012.07.029

Juliani, H. R., Welch, C., Asante-Dartey, J., Wang, M., and Simon, J. E. (2008). "Chemistry, quality and functional properties of grains of paradise (Aframomum melegueta), a rediscovered spice," in Dietary Supplements, eds C. T. Ho, J. E. Simon, F. Shahidi, and Y. Shao (Washington, DC: ACS), 100-113.

Juliani, R. H., Koroch, A. R., Giordano, L., Amekuse, L., Koffa, S., and AsanteDartey, J., et al. (2013). "Piper guineense (Piperaceae): chemistry, traditional uses, and functional properties of west african black pepper, Chapter 3," in African Natural Plant Products Volume II: Discoveries and Challenges in Chemistry, Health, and Nutrition, American Chemical Society, eds H. R. Juliani, J. E. Simon, and C.-T. Ho (New Jersey), 33-48.

Kaefer, C. M., and Milner, J. A. (2008). The role of herbs and spices in cancer prevention. J. Nutr. Biochem. 19, 347-361. doi: 10.1016/j.jnutbio.2007.11.003

Kamdem, D., and Douglas, G. (2007). Chemical composition of essential oil from the root bark of Sassafras albidum. Planta Med. 61, 574-575. doi: 10.1055/s2006-959379

Kapoor, I. P. S., Singh, B., Singh, S., and Singh, G. (2014). Essential oil and oleoresins of black pepper as natural food preservatives for orange juice. J. Food Process. Preserv. 38, 146-152. doi: 10.1111/j.1745-4549.2012.00756.x

Kaushik, D., Yadav, J., Kaushik, P., Sacher, D., and Rani, R. (2011). Current pharmacological and phytochemical studies of the plant Alpinia galanga. J. Chin. Integr. Med. 9, 1061-1065. doi: 10.3736/jcim20111004

Kedia, A., Prakash, B., Mishra, K. P., and Dubey, N. K. (2014). Antifungal and antiaalfatoxigenic properties of Cuminum cyminum (L.) seed essential oil and its efficacy as a preservative in stored commodities. Int. J. Food Microbiol. 168-169, 1-7. doi: 10.1016/j.ijfoodmicro.2013.10.008

Khan, M., and Siddiqui, M. (2007). Antimicrobial activity of Piper fruits. Nat. Prod. Radiance 6, 111-113.

Khan, R., Zakir, M., Afaq, S. H., Latif, A., and Khan, A. U. (2010). Activity of solvent extracts of Prosopis spicigera, Zingiber officinale and Trachyspermum ammi against multidrug resistant bacterial and fungal strains. J. Infect. Dev. Ctries. 4, 292-300. doi: 10.3855/jidc.621

Kim, K. K., Park, H. C., Son, H. J., Kim, Y. G., Lee, S. M., Choi, I. S., et al. (2007). Antimicrobial and anticancer activity of Korean traditional soy sauce and paste with Chopi. J. Life Sci. 17, 1121-1128. doi: 10.5352/JLS.2007.17. 8.1121

Kim, S., and Fung, D. Y. C. (2003). “Antibacterial effect of crude water-soluble arrowroot (Maranta arundinacea) tea extracts on food-borne pathogens in liquid medium," in Session 29F, Food Microbiology: Control of Foodborne Microorganisms by Antimicrobials (Chicago, IL: IFT Annual Meeting).

Kim, Y. S., Ahn, E. S., and Shin, D. H. (2002). Extension of shelf life by treatment with allyl isothiocyanate in combination with acetic acid on cooked rice. J. Food Sci. 67, 274-279. doi: 10.1111/j.1365-2621.2002.tb11397.x

Kingchaiyaphum, W., and Rachtanapun, C. (2012). Antimicrobial and antioxidative activities of essential oils in Chinese sausage (Kun-Chiang). Asian J. Food Agro Ind. 5, 156-162.

Koa, J. A., Kima, W. Y., and Parka, H. J. (2012). Effects of microencapsulated Allyl isothiocyanate (AITC) on the extension of the shelf-life of Kimchi. Int. J. Food Microbiol. 153, 92-98. doi: 10.1016/j.ijfoodmicro.2011.10.021

Koffi-Nevry, R., Kouassi, C., Nanga, Y. Z., Koussémon, M., and Loukou, G. Y. (2012). Antibacterial activity of two bell pepper extracts: Capsicum annuum L. and Capsicum frutescens. Int. J. Food Prop. 15, 961-971. doi: 10.1080/10942912.2010.509896

Krisch, J., Tserennadmid, R., and Vágvölgy, C. (2011). “Essential oils against yeasts and moulds causing food spoilage," in Science against Microbial Pathogens: Communicating Current Research and Technological Advances, ed A. MéndezVilas (Badajoz: Formatex Research Center), 1135-1142.

Kumar, H., Shanmugavadivu, M., Rajamania, R., and Kuppsamy, S. (2014). Antibacterial activity of different solvent extracts of medicinal plant: Ruta graveolens L. Int. J. Biosci. Nanosci. 1, 9-11.

Kumar, K. N., Venkataramana, M., Allen, J. A., Chandranayaka, S., Murali, H. S., and Batra, H. V. (2016). Role of Curcuma longa L. essential oil in controlling the growth and zearalenone production of Fusarium graminearum. LWT Food Sci. Technol. 69, 522-528. doi: 10.1016/j.lwt.2016.02.005

Leeja, L., and Thopil, J. E. (2007). Antimicrobial activity of methanol extract of Origanum majorana L. (Sweet marjoram). J. Environ. Biol. 28, 145-146.

Li, Y., Zeng, T., Chen, P., Song, Y., Luo, Y., and Wang, Q. (2015). Enhancement of aqueous stability of allyl isothiocyanate using nanoemulsions prepared by an emulsion inversion point method. J. Colloid Interface Sci. 438, 130-137. doi: 10.1016/j.jcis.2014.09.055

Lv, F., Liang, H., Yuan, Q., and Li, C. (2011). In vitro antimicrobial effects and mechanism of action of selected plant essential oil combinations against four food-related microorganisms. Food Res. Inter. 44, 3057-3064. doi: 10.1016/j.foodres.2011.07.030

Mahendra, P., and Bisht, S. (2012). Ferula asafoetida: traditional uses and pharmacological activity. Pharmacogn. Rev. 6, 141-146. doi: 10.4103/09737847.99948

Maisanaba, S., Llana-Ruiz-Cabello, M., Gutiérrez-Praena, D., Pichardo, S., Puerto, M., Prieto, A. I., et al. (2016). New advances in active packaging incorporated with essential oils or their main components for food preservation. Food Rev. Int. doi: 10.1080/87559129.2016.1175010. [Epub ahead of print].

Malti, J. E., Mountassif, D., and Amarouch, H. (2007). Antimicrobial activity of Elettaria cardamomum: toxicity, biochemical and histological studies. Food Chem. 104, 1560-1568. doi: 10.1016/j.foodchem.2007.02.043

Marchese, A., Orhan, I. E., Daglia, M., Barbieri, R., Lorenzo, A. D., Nabavi, S. F., et al. (2016). Antibacterial and antifungal activities of thymol: a brief review of the literature. Food Chem. 210, 402-404. doi: 10.1016/j.foodchem.2016.04.111

Mazidi, S., Rezaei, K., Golmakani, M. T., Sharifan, A., and Rezazadeh, S. H. (2012). Antioxidant activity of essential oil from black zira (Bunium persicum Boiss.) obtained by microwave-assisted hydrodistillation. J. Agri. Sci. Techn. 14, 1013-1022.

McKay, D. L., and Blumberg, J. B. (2006). A review of the bioactivity and potential health benefits of peppermint tea (Mentha piperita L.). Phytother. Res. 20, 619-633. doi: 10.1002/ptr.1936

Menon, S., and Nayeem, N. (2013). Vanilla planifolia: a review of a plant commonly used as flavouring agent. Int. J. Pharm. Sci. Rev. Res. 20, 225-228.

Miceli, A., Aleo, A., Corona, O., Sardina, M. T., Mammina, C., and Settanni, L. (2014). Antibacterial activity of Borago officinalis and Brassica juncea aqueous extracts evaluated in vitro and in situ using different food model systems. Food Control 40, 157-164. doi: 10.1016/j.foodcont.2013.12.006

Mihajilov-Krstev, T., Kitic, D., Stojanovic-Radic, Z., and Zlatkovic, B. (2010). Antimicrobial activity of Satureja hortensis L.essential oil against pathogenic microbial strains. Arch. Biol. Sci. 62, 159-166. doi: 10.2298/ABS1001159M

Moghadamtousi, S. Z., Kadir, H. A., Hassandarvish, P., Tajik, H., Sazaly Abubakar, S., and Zandi, K. (2014). A review on antibacterial, antiviral, and antifungal activity of curcumin. Biomed. Res. Int. 2014:186864. doi: 10.1155/2014/186864

Moghaddam, A. M. D., Shayegh, J., Mikaili, P., and Sharaf, J. D. (2011). Antimicrobial activity of essential oil extract of Ocimum basilicum L. leaves on a variety of pathogenic bacteria. J. Med. Plant Res. 5, 3453-3456.

Mokaddem, D. H., Kabouche, A., Bouacha, M., Soumati, B., El-Azzouny, A., Bruneau, C., et al. (2010). GC/MS analysis and antimicrobial activity of the essential oil of fresh leaves of Eucalytus globulus, and leaves and stems of Smyrnium olusatrum from Constantine (Algeria). Nat. Prod. Comm. 5, 1669-1672.

Moradkhani, H., Sargsyan, E., Bibak, H., Naseri, B., Sadat-Hosseini, M., FayaziBarjin, A., et al. (2010). Melissa officinalis L., a valuable medicine plant: a review. J. Med. Plants Res. 25, 2753-2759.

Moyeenul Huq, A. K. M., Jamal, J. A., and Stanslas, J. (2014). Ethnobotanical, phytochemical, pharmacological, and toxicological aspects of Persicaria 
hydropiper (L.) Delarbre. J. Evid. Based Complement. Altern. Med. 2014:782830. doi: $10.1155 / 2014 / 782830$

Mucete, D., Borozan, A., Radu, F., and Jianu, I. (2006). Antibacterial activity of isothyocianates, active principles in Armoracia rusticana roots (II). J. Agroal. Process. Technol. 12, 443-452.

Nakata, M., Myoda, T., Wakita, Y., Sato, T., Tanahashi, I., Toeda, K., et al. (2013). Volatile components of essential oil from cultivated Myrica gale var. tomentosa and its antioxidant and antimicrobial activities. J. Oleo Sci. 62, 755-762. doi: $10.5650 /$ jos. 62.755

Naveed, R., Hussain, I., Tawab, A., Tariq, M., Rahman, M., Hameed, S., et al. (2013). Antimicrobial activity of the bioactive components of essential oils from Pakistani spices against Salmonella and other multi-drug resistant bacteria. BMC Complement. Altern. Med. 13:265. doi: 10.1186/1472-6882-13-265

Naveena, B. M., Muthukumar, M., Sen, A. R., Babji, Y., and Murthy, T. R. K. (2006). Improvement of shelf-life of buffalo meat using lactic acid, clove oil and vitamin C during retail display. Meat Sci. 74, 409-415. doi: 10.1016/j.meatsci.2006.04.020

Nerilo, S. B., Rocha, G. H. O., Tomoike, C., Mossini, S. A., Grespan, R., Mikcha, J. M., et al. (2016). Antifungal properties and inhibitory effects upon aflatoxin production by Zingiber officinale essential oil in i. Int. J. Food Sci. Technol. 51, 286-292. doi: 10.1111/ijfs.12950

Ng, D. S. H., Rose, L. C., Suhaimi, H., Mohamad, H., Rozaini, M. Z. H., and Taib, M. (2011). Preliminary evaluation on the antibacterial activities of Citrus hystris oil emulsions stabilized by twen 80 and span 80. Int. J. Pharm. Pharm. Sci. 3(Suppl. 2), 209.

Ngang, J. J., Nyegue, M. A., Ndoye, F. C., Tchuenchieu Kamgain, A. D., Sado Kamdem, S. L., Lanciotti, R., et al. (2014). Characterization of mexican coriander (Eryngium foetidum) essential oil and its inactivation of Listeria monocytogenes in vitro and during mild thermal pasteurization of pineapple juice. J. Food Prot. 3, 352-521. doi: 10.4315/0362-028x.jfp-13-323

Nneka, V. C., and Jude, A. U. (2012). Antimicrobial properties and phytochemical analysis of methanolic extracts of Aframomum melegueta and Zingiber officinale on fungal diseases of tomato fruit. J. Nat. Sci. Res. 2, 10-15.

Nwinyi, O. C., Chinedu, N. S., Ajani, O. O., Ikpo, C., Ogunniran, and Kehinde, O. (2009). Antibacterial effects of extracts of Ocimum gratissimum and Piper guineense on Escherichia coli and Staphylococcus aureus. Afr. J. Food Sci. 3, $022-025$.

O’Bryan, C. A., Pendleton, S. J., Crandall, P. G., and Ricke, S. C. (2015). Potential of plant essential oils and their components in animal agriculture in vitro studies on antibacterial mode of action. Front. Vet. Sci. 2:35. doi: 10.3389 /fvets. 2015.00035

Obolskiy, D., Pischel, I., Feistel, B., Glotov, N., and Heinrich, M. (2011). Artemisia dracunculus L. (Tarragon): A critical review of its traditional use, chemical composition, pharmacology, and safety. J. Agri. Food Chem. 59, 11367-11384. doi: $10.1021 / \mathrm{jf} 202277 \mathrm{w}$

Odoh, U. E., Ezugwu, C. O., and Ajali, I. U. (2004). Antimicrobial activity of Monodora myristica seed oil. J. Pharm. Allied Sci. 2, 233-236. doi: 10.4314/ jophas.v2i2.34983

Ogunsola, O. K., and Fasola, T. R. (2014). The antibacterial activities of Sesamum indicum Linn. leaf extracts. Adv. Sci. Tech. 18, 28-32.

Omezzine, F., Bouaziz, M., Daami-Remadi, M., Simmonds, M. S. J., and Haouala, R. (2014). Chemical composition and antifungal activity of Trigonella foenumgraecum L. varied with plant ploidy level and developmental stage. Arab. J. Chem. doi: 10.1016/j.arabjc.2014.03.013. Available online at: http://www. readcube.com/articles/10.1016/j.arabjc.2014.03.013

Owokotomo, I. A., and Ekundayo, O. (2012). Comparative study of the essential oils of Monodora myristica from Nigeria. Eur. Chem. Bull. 1, 263-265.

Özcan, M. M., and Chalchat, J. C. (2008). Chemical composition and antifungal activity of rosemary (Rosmarinus officinalis L.) oil from Turkey. Int. J. Food Sci. Nutr. 59, 691-698. doi: 10.1080/09637480701777944

Ozer, M. S., Sarikurkcu, C., Tepe, B., and Can, S. (2010). Essential oil composition and antioxidant activities of alkanet (Alkanna tinctoria subsp. tinctoria). Food Sci. Biotechnol. 19, 1177-1183. doi: 10.1007/s10068-010-0168-x

Paaver, U., Orav, A., Mäeorg, E. A. U., and Ain Raal, A. (2008). Phytochemical analysis of the essential oil of Thymus serpyllum L. growing wild in Estonia. Nat. Prod. Res. 22, 108-115. doi: 10.1080/14786410601035118

Pathan, R. K., Gali, P. R., Pathan, P., Gowtham, T., and Pasupuleti, S. (2012). In vitro antimicrobial activity of Citrus aurantifolia and its phytochemical screening. Asian Pac. J. Trop. Dis. 2, S328-S331. doi: 10.1016/S2222-1808(12) 60176-5

Patrignani, F., Siroli, L., Serrazanetti, D. I., Gardini, F., and Lanciotti, R. (2015). Innovative strategies based on the use of essential oils and their components to improve safety, shelf-life and quality of minimally processed fruits and vegetables. Trends Food Sci. Tech. 46, 311-319. doi: 10.1016/j.tifs.2015.03.009

Patrignani, F., Tabanelli, G., Siroli, L., Gardini, F., and Lanciotti, R. (2013). Combined effects of high pressure homogenization treatment and citral on microbiological quality of apricot juice. Int. J. Food Microbiol. 160, 273-281. doi: 10.1016/j.ijfoodmicro.2012.10.021

Peerakam, N., Wattanathorn, J., Suchart, P., Buamongkol, S., Sirisa-ard, P., and Chansakaow, S. (2014). Chemical profiling of essential oil composition and biological evaluation of Anethum graveolens L. (Seed) grown in Thailand. J. Nat. Sci. Res. 4, 34-41.

Pilau, M. R., Alves, S. H., Weiblen, R., Arenhart, S., Cueto, A. P., and Lovato, L. T. (2011). Antiviral activity of the Lippia graveolens (Mexican oregano) essential oil and its main compound carvacrol against human and animal viruses. Braz. J. Microbiol. 42, 1616-1624. doi: 10.1590/S1517-83822011000400049

Pina-Pérez, M. C., Martínez-López, A., and Rodrigo, D. (2012). Cinnamon antimicrobial effect against Salmonella Typhimurium cells treated by pulsed electric fields (PEF) in pasteurized skim milk beverage. Food Res. Int. 48, 777-783. doi: 10.1016/j.foodres.2012.06.027

Prakash, B., Shukla, R., Singh, P., Kumar, A., Mishra, P. K., and Dubey, N. K. (2010). Efficacy of chemically characterized Piper betle L. essential oil against fungal and aflatoxin contamination of some edible commodities and its antioxidant activity. Int. J. Food Microbiol. 15, 114-119. doi: 10.1016/j.ijfoodmicro.2010.06.011

Prakash, B., Singh, P., Kedia, A., and Dubey, N. K. (2012). Assessment of some essential oils as food preservatives based on antifungal, antiaflatoxin, antioxidant activities and in vivo efficacy in food system. Food Res. Int. 49, 201-208. doi: 10.1016/j.foodres.2012.08.020

Prasad, S., Gupta, S. C., and Aggarwal, B. B. (2011). Micronutrients and cancer: add spice to your life. Nutr. Diet Cancer 23-48. doi: 10.1007/978-94-007-2923-0_2

Przygodzka, M., Zielinska, D., Ciesarová, Z., Kukurová, K., and Zielinski, H. (2014). Comparison of methods for evaluation of the antioxidant capacity and phenolic compounds in common spices. LWT Food Sci. Technol. 58, 1-6. doi: 10.1016/j.lwt.2013.09.019

Radha, K. K., Babuskin, S., Azhagu Saravana Babu, P., Sasikala, M., Sabina, K., Archana, G., et al. (2014). Antimicrobial and antioxidant effects of spice extracts on the shelf life extension of raw chicken meat. Int. J. Food Microbiol. 171, 32-40. doi: 10.1016/j.ijfoodmicro.2013.11.011

Radwan, M. M., Tabanca, N., Wedge, D. E., Tarawneh, A. H., and Cutler, S. J. (2014). Antifungal compounds from turmeric and nutmeg with activity against plant pathogens. Fitoterapia 99, 341-346. doi: 10.1016/j.fitote.201 4.08 .021

Raeisi, M., Tajik, H., Razavi Roohani, S., Maham, M., Moradi, M., Hajimohammadi, B., et al. (2012). Essential oil of tarragon (Artemisia dracunculus) antibacterial activity on Staphylococcus aureus and Escherichia coli in culture media and Iranian white cheese. Iran J. Microbiol. 4, $30-34$.

Rajamurugan, R., Selvaganabathy, N., Kumaravel, S., Ramamurthy, Ch., Sujatha, V., and Thirunavukkarasu, C. (2012). Polyphenol contents and antioxidant activity of Brassica nigra (L.) Koch. leaf extract. Nat. Prod. Res. 26, 2208-2210. doi: 10.1080/14786419.2011.637215

Rajashekhara, N., Vinay, J., Shukla, B., Ravishankar, B., and Parameshwar Sharma, P. (2013). Comparative physico-chemical profiles of Tugaksheeree (Curcuma angustifolia Roxb. and Maranta arundinacea Linn.). Ayu 34, 401-405. doi: $10.4103 / 0974-8520.127723$

Rancic, A., Sokovic, M., Vukojevic, J., Simic, A., Marin, P., Duletic-Lausevic, S., et al. (2005). Chemical composition and antimicrobial activities of essential oils of Myrrhis odorata (L.) Scop, Hypericum perforatum L and Helichrysum arenarium (L.) Moench. J. Essent. Oil Res. 17, 341-345. doi: 10.1080/10412905.2005.9698925

Rather, R. A., Rehman, S., Syed Naseer, S., Lone, S., Bhat, K. A., and Chouhan, A. (2013). Flash chromatography guided fractionation and antibacterial activity studies of Angelica archangelica root extracts. J. Appl. Chem. 4, 34-38.

Rattanachaikunsopon, P., and Phumkhachorn, P. (2008). Diallylsulfide content and antimicrobial activity against food-borne pathogenic bacteria of chives 
(Allium schoenoprasum). Biosci. Biotechnol. Biochem. 72, 2987-2991. doi: $10.1271 /$ bbb. 80482

Ravindran, M. K. (ed.). (2002). Cardamom: The Genus Elettaria. New York, NY: Taylor and Francis.

Routray, W., and Rayaguru, K. (2010). Chemical constituents and post-harvest prospects of Pandanus amaryllifolius leaves: a review. Food Rev. Int. 26, 230-245. doi: 10.1080/87559129.2010.484114

Rubió, L., Motilva, M. J., and Romero, M. P. (2013). Recent advances in biologically active compounds in herbs and spices: a review of the most effective antioxidant and anti-inflammatory active principles. Crit. Rev. Food Sci. Nutr. 53, 943-953. doi: 10.1080/10408398.2011.574802

Sadia, S., Khalid, S., Qureshi, R., and Bajwa, A. A. (2013). Tagetes minuta L., a useful underutilized plant of family Asteraceae: a review. Pak. J. Weed Sci. Res. 19, 179-189.

Saharkhiz, M. J., Motamedi, M., Zomorodian, K., Pakshir, K., Miri, R., and Kimia Hemyari, K. (2012). Chemical composition, antifungal and antibiofilm activities of the essential oil of Mentha piperita L. Pharmaceutics 2012:718645. doi:10.5402/2012/718645

Sasongko, P., Laohankunjit, N., and Kerdchoechuen, O. (2011). Antibacterial Activity of the essential oil from Persicaria odorata Leaves. J. Agr. Sci. 42, 105-108.

Saladino, F., Bordin, K., Manyes, L., Luciano, F. B., Ma-es, J., FernándezFranzón, M., et al. (2016). Reduction of the aflatoxins B1, B2, G1 and G2 in Italian piadina by isothiocyanates. LWT Food Sci. Technol. 70, 302-308. doi: 10.1016/j.lwt.2016.03.006

Savan, E. K., and Kucukbay, Z. F. (2013). Essential oil composition of Elettaria cardamomum Maton. J. Appli. Biol. Sci. 7, 42-45.

Senatore, F., Napolitano, F., Mohamed, M., Harris, P. J. C., and Mnkeni, P. N. S. (2004). Antibacterial activity of Tagetes minuta L. (Asteraceae) essential oil with different chemical composition. Flavour Frag. J. 19, 574-578. doi: 10.1002/ffj. 1358

Sessou, P., Farougou, S., and Sohounhloué, D. (2012). Major component and potential applications of plant essentials oils as natural food preservatives: a short review research results. Int. J. Biosci. 2, 45-57.

Sethi, S., Dutta, A., Gupta, B. L., and Gupta, S. (2013). Antimicrobial activity of spices against isolated food borne pathogens. Int. J Pharm. Pharm. Sci. 5, 260-262.

Shabir, A. (2012). Rhus coriaria Linn, a plant of medicinal, nutritional and industrial importance: a review. J. Anim. Plant Sci. 2, 505-512.

Shahat, A. A., Ibrahim, A. Y., Hendawy, S. F., Omer, E. A., Hammouda, F. M., Abdel-Rahman, F. H., et al. (2011). Chemical composition, antimicrobial and antioxidant activities of essential oils from organically cultivated fennel cultivars. Molecules 16, 1366-1377. doi: 10.3390/molecules 16021366

Shan, B., Cai, Y. Z., Brooks, J. D., and Corke, H. (2007). The in vitro antibacterial activity of dietary spice and medicinal herb extracts. Int. J. Food Micro. 117, 112-119. doi: 10.1016/j.ijfoodmicro.2007.03.003

Shanmugavalli, N., Umashankar, V., and Raheem (2009). Antimicrobial activity of Vanilla planifolia. Indian J. Sci. Technol. 2, 39-40.

Sharafi, S. M., Rasooli, I., Owlia, P., Taghizadeh, M., and Astaneh, S. A. (2010). Protective effects of bioactive phytochemicals from Mentha piperita with multiple health potentials. Pharmacogn. Mag. 6, 147-153. doi: 10.4103/09731296.66926

Sharon, H., Baccus-Taylor, G. S. H., Akingbala, and John, A. (2007). “Antibacterial efficacy of Eryngium foetidum (Culantro) against select food-borne pathogens," in CAES: 27th West Indies Agricultural Economics Conference (Belize), 179-192.

Shavandi, M. A., Haddadian, Z., and Ismail, M. H. S. (2012). Eryngium foetidum L. Coriandrum sativum and Persicaria odorata L.: a review. J. Asian Sci. Res. 2, 410-426.

Shirazi, M. T., Gholami, H., Kavoosi, G., Rowshan, V., and Tafsiry, A. (2014). Chemical composition, antioxidant, antimicrobial and cytotoxic activities of Tagetes minuta and Ocimum basilicum essential oils. Food Sci. Nutr. 2, 146-155. doi: $10.1002 /$ fsn 3.85

Shirshova, T., Beshlei, I., Deryagina, V., Ryzhova, N., and Matistov, N. (2013). Chemical composition of Allium schoenoprasum leaves and inhibitory effect of their extract on tumor growth in mice. Pharm. Chem. J. 46, 11, 672-675. doi: $10.1007 /$ s11094-013-0867-8
Shiva Rani, S. K., Neeti, S., and Udaysree (2013). Antimicrobial activity of black pepper (Piper nigrum L.). Glob. J. Pharmacol. 7, 87-90. doi: 10.5829/idosi.gjp.2013.7.1.1104

Simons, V., Morrissey, J. P., Latijnhouwers, M., Csukai, M., Cleaver, A., Yarrow, C., et al. (2006). Dual effects of plant steroidal alkaloids on Saccharomyces cerevisiae. Antimicrob. Agents Chemother. 50, 2732-2740. doi: 10.1128/AAC.00289-06

Singh, G., Maurya, S., DeLampasona, M. P., and Catalan, C. A. N. (2007). A comparison of chemical, antioxidant and antimicrobial studies of cinnamon leaf and bark volatile oils, oleoresins and their constituents. Food Chem. Toxicol. 45, 1650-1661. doi: 10.1016/j.fct.2007.02.031

Siroli, L., Patrignani, F., Montanari, C., Tabanelli, G., Bargossi, E., Gardini, F., et al. (2014b). Characterization of oregano (Origanum vulgare) essential oil and definition of its antimicrobial activity against Listeria monocytogenes and Escherichia coli in vitro system and on foodstuff surfaces. Afr. J. Microbiol. Res. 8, 2746-2753. doi: 10.5897/AJMR2014.6677

Siroli, L., Patrignani, F., Serrazanetti, D. I., Tabanelli, G., Montanari, C., Tappi, S., et al. (2014a). Efficacy of natural antimicrobials to prolong the shelf-life of minimally processed apples packaged in modified atmosphere. Food Control 46, 403-411. doi: 10.1016/j.foodcont.2014.05.049

Skrinjar, M. M., and Nemet, N. T. (2009). Antimicrobial effect of spices and herbs essential oils. Acta Period. Technol. 40, 195-209. doi: 10.2298/APT09 40195S

Spadaro, F., Costa, R., Circosta, C., and Occhiuto, F. (2012). Volatile composition and biological activity of key lime Citrus aurantifolia essential oil. Nat. Prod. Commun. 7, 1523-1526.

Srinivasan, K. (2014). Antioxidant potential of spices and their active constituents. Crit. Rev. Food Sci. Nutr. 54, 352-372. doi: 10.1080/10408398.2011.585525

Stoilova, I., Krastanov, A., Stoyanova, A., Denev, P., and Gargova, S. (2007). Antioxidant activity of a ginger extract (Zingiber officinale). Food Chem. 102, 764-770. doi: 10.1016/j.foodchem.2006.06.023

Süleyman, K., Hasimi, N., Tolan, V., Kilininc, E., and Karatas, H. (2010). Chemical composition, antimicrobial and antioxidant activities of hyssop (Hyssopus officinalis L.) essential oil. No-tulae Botanicae Horti Agrobotanici Cluj-Napoca 38, 99-103. doi: 10.15835/nbha3834788

Sultana, S., Ripa, F. A., and Hamid, K. (2010). Comparative antioxidant activity study of some commonly used spices in Bangladesh. Pak. J. Biol. Sci. 13, 340-343. doi: 10.3923/pjbs.2010.340.343

Sung, B., Prasad, S., Yadav, V. R., and Aggarwal, B. B. (2012). Cancer cell signaling pathways targeted by spice-derived nutraceuticals. Nutr. Cancer 64, 173-197. doi: 10.1080/01635581.2012.630551

Szabo, M. A., Varga, G. Z., Hohmann, J., Schelz, Z., Szegedi, E., Amaral, L., et al. (2010). Inhibition of quorum-sensing signals by essential oils. Phytother Res. 24, 782-786. doi: 10.1002/ptr.3010

Tabanelli, G., Montanari, C., Patrignani, F., Siroli, L., Lanciotti, R., and Gardini, F. (2014). Modeling with the logistic regression of the growth/no growth interface of Saccharomyces cerevisiae in relation to 2 antimicrobial terpenes (Citral and Linalool), pH, and aw. J. Food Sci. 79, M391-M398. doi: 10.1111/17503841.12369

Tabassum, N., and Vidzasagar, G. M. (2013). Antifungal investigations on plant essential oils. a review. Int. J. Pharm. Pharm. Sci. 5(Suppl. 2), 19-28.

Tajkarimi, M. M., Ibrahim, S. A., and Cliver, D. O. (2010). Antimicrobial herb and spice compounds in food. Food Control 21, 1199-1218. doi: 10.1016/j.foodcont.2010.02.003

Tejeswini, M. G., Sowmya, H. V., Swarnalatha, S. P., and Negi, P. S. (2014). Antifungal activity of essential oils and their combinations in in vitro and in vivo conditions. Arch. Phytopathol. Plant Protect. 47, 564-570. doi: 10.1080/03235408.2013.814235

Torabbeigi, M., and Azar, P. A. (2013). Analysis of essential oil compositions of Lavandula angustifolia by HS-SPME and MAHS- SPME Followed by GC and GC-MS. Acta Chromatogr. 25, 1-9. doi: 10.1556/AChrom.25.2013.3.12

Tyagi, A. K., Bukvicki, D., Gottardi, D., Tabanelli, G., Montanari, C., Malik, A., et al. (2014b). Eucalyptus essential oil as a natural food preservative: in vivo and in vitro anti-yeast potential. Biomed Res. Int. 2014:969143. doi: 10.1155/ 2014/969143

Tyagi, A. K., Gottardi, D., Malik, A., and Guerzoni, M. E. (2013). Antiyeast activity of mentha oil and vapours through in vitro and in vivo real 
fruit juices assays. Food Chem. 137, 108-114. doi: 10.1016/j.foodchem.2012. 10.015

Tyagi, A. K., Gottardi, D., Malik, A., and Guerzoni, M. E. (2014a). Chemical composition, in vitro anti-yeast activity and fruit juice preservation potential of lemon grass oil. LWT Food Sci. Technol. 57, 731-737. doi: 10.1016/j.lwt.2014. 02.004

Tyagi, A. K., and Malik, A. (2010a). Antimicrobial action of essential oil vapours and negative air ions against Pseudomonas fluorescens. Int. J. Food Microbiol. 143, 205-210. doi: 10.1016/j.ijfoodmicro.2010. 08.023

Tyagi, A. K., and Malik, A. (2010b). Liquid and vapour-phase antifungal activities of selected essential oils against Candida albicans: microscopic observations and chemical characterization of Cymbopogon citratus. BMC Complement. Altern. Med. 10:65. doi: 10.1186/1472-6882-10-65

Tyagi, A. K., and Malik, A. (2010c). In situ SEM, TEM and AFM studies of the antimicrobial activity of lemon grass oil in liquid and vapour phase against Candida albicans. Micron 41, 797-805. doi: 10.1016/j.micron.2010. 05.007

Tyagi, A. K., and Malik, A. (2011). Antimicrobial potential and chemical composition of Mentha piperita oil in liquid and vapour phase against food spoiling microorganisms. Food Control 22, 1707-1714. doi: 10.1016/j.foodcont.2011.04.002

Tyagi, A. K., and Malik, A. (2012). Bactericidal action of lemon grass oil vapors and negative air ions. Innov. Food Sci. Emerg. Technol. 13, 169-177. doi: 10.1016/j.ifset.2011.09.007

Umar, M. I., Asmawi, M. Z. B., Sadikun, A., Altaf, R., and Iqbal, M. A. (2011). Phytochemistry and medicinal properties of Kaempferia galanga L.(Zingiberaceae) extracts. Afr. J. Pharm. Pharmacol. 5, 1638-1647. doi: 10.5897/AJPP11.388

Unlu, M., Ergene, E., Unlu, G. V., Zeytinoglu, H. S., and Vural, N. (2010). Composition, antimicrobial activity and in vitro cytotoxicity of essential oil from Cinnamomum zeylanicum blume (lauraceae). Food Chem. Toxicol. 48, 3274-3280. doi: 10.1016/j.fct.2010.09.001

Upadhyay, R. K., Ahmad, S., Jaiswal, G., Dwivedi, P., and Tripathi, R. (2008). Antimicrobial effects of Cleome viscosa and Trigonella foenum graecum seed extracts. J. Cell Tissue Res. 8, 1355-1360.

Vazirian, M., Kashani, S. T., Ardekani, M. R. S., Khanavi, M., Jamalifar, H., Reza, M., et al. (2012). Antimicrobial activity of lemongrass (Cymbopogon citratus (DC) Stapf.) essential oil against food-borne pathogens added to cream-filled cakes and pastries. J. Ess. Oil Res. 24, 579-582. doi: 10.1080/10412905.2012.729920

Vyry Wouatsa, N. A., Misra, L., and Venkatesh Kumar, R. (2014). Antibacterial activity of essential oils of edible spices, Ocimum canum and Xylopia aethiopica. J. Food Sci. 79, M972-M977. doi: 10.1111/1750-3841.12457

Weerakkody, N. S., Caffin, N., Turner, M. S., and Dykes, G. A. (2010). In vitro antimicrobial activity of less-utilized spice and herb extracts against selected food-borne bacteria. Food Control 21, 1408-1414. doi: 10.1016/j.foodcont.2010.04.014

Woguem, V., Maggi, F., Fogang, H. P., Tapondjoua, L. A., Womeni, H. M., Luana, Q., et al. (2013). Antioxidant, antiproliferative and antimicrobial activities of the volatile oil from the wild pepper Piper capense used in Cameroon as a culinary spice. Nat. Prod. Comm. 8, 1791-1796.

$\mathrm{Xu}$, S., Yan, F., Ni, Z., Chen, Q., Zhang, H., and Zheng, X. (2014). In vitro and in vivo control of Alternaria alternata in cherry tomato by essential oil from Laurus nobilis of Chinese origin. J. Sci. Food Agric. 94, 1403-1408. doi: 10.1002/jsfa.6428

Yadav, A. S., and Singh, R. (2004). Natural preservatives in poultry meat. Indian. J. Nat. Prod. Resour. 3, 300-303.

Zheng, C. J., Li, L., Ma, W. H., Han, T., and Qin, L. P. (2011). Chemical constituents and bioactivities of the liposoluble fraction from different medicinal parts of Crocus sativus. Pharm. Biol. 49, 756-763. doi: 10.3109/13880209.2010. 547206

Zhu, R. X., Zhong, K., Zeng, W. C., He, X. Y., Gu, X. Q., Zhao, Z. F., et al. (2011). Essential oil composition and antibacterial activity of Zanthoxylum bungeanum. Afr. J. Microbiol. Res. 5, 4631-4637. doi: 10.5897/AJMR11.772

Conflict of Interest Statement: The authors declare that the research was conducted in the absence of any commercial or financial relationships that could be construed as a potential conflict of interest.

Copyright (C) 2016 Gottardi, Bukvicki, Prasad and Tyagi. This is an open-access article distributed under the terms of the Creative Commons Attribution License (CC $B Y)$. The use, distribution or reproduction in other forums is permitted, provided the original author(s) or licensor are credited and that the original publication in this journal is cited, in accordance with accepted academic practice. No use, distribution or reproduction is permitted which does not comply with these terms. 